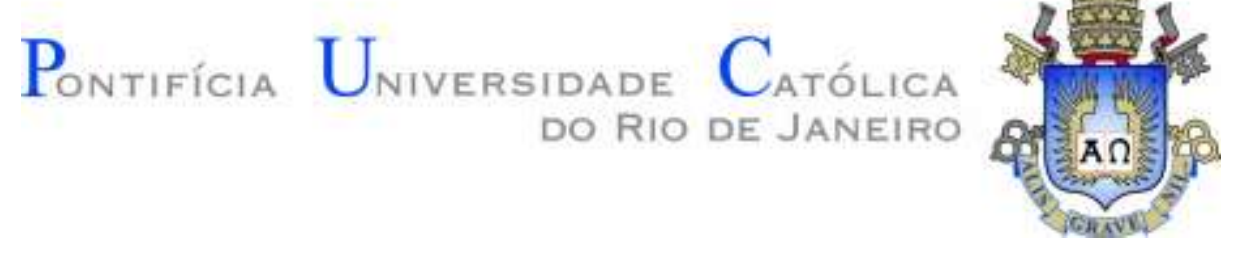

Natalie Gerhardt

REPRESENTATION OF CHARACTERS

IN J. K. ROWLING'S BOOKS:

\title{
A SYSTEMIC FUNCTIONAL PERSPECTIVE
}

Monografia apresentada ao Programa de Pós-graduação latu-sensu em Língua Inglesa da PUC-Rio

Orientadora: Prof. Mônica Souza Departamento de Letras - PUC-Rio

Rio de Janeiro, 29 de junho de 2016 
To my husband, Leo, and my son, Enzo for all the love, support and patience. 


\section{Acknowledgement}

To my dear supervisor Professor Mônica Souza, for believing in this project and stimulating me to go on.

To my twin, Michele, and my baby brother, Victor, for having faith and confidence that I can make my dreams come true, even when I have my doubts.

To my parents, for all love, education and care.

To my professors and colleagues from PUC-Rio's graduate program for encouraging me to keep the theme I chose in the beginning of our course. 


\section{Abstract}

Gerhardt, Natalie. Representation of characters in J. K. Rowling's books: a systemic functional perspective. Rio de Janeiro, 2016. Monografia de PósGraduação - Departamento de Letras, Pontifícia Universidade Católica do Rio de Janeiro.

J. K. Rowling's writing is very successful among children and adult readers. The purpose of this monograph is to make a documental analysis (BOWEL, 2009) of 17 excerpts from the first two chapters of Harry Potter and the Philosopher's Stone (ROWLING, 1997, pp. 7-27) and 10 excerpts from The Cuckoo's Calling (GALBRAITH, 2013, pp. 13-23) to understand, from a Systemic Functional Linguistics perspective (HALLIDAY; MATHIESSEN, 2004), the author's linguistic choices to build the heroes - Harry Potter and Cormoran Strike. The focus of the analysis is on the transitivity system, in other words the clause as representation of the protagonists' experience. The elements that will be analyzed are the processes, circumstances and attributes related to the heroes as participants. The analysis of processes indicated that the author uses a mix of all process types to construe her protagonists and not only relational clauses followed by attributes (HALLIDAY; MATHIESSEN, 2004, p. 174). Regarding circumstances, in addition to using them to add more information to the clauses, like location, manner, cause, etc., Rowling also uses them as clues to what is going to happen and to add more movement and energy to the scenes.

\section{Key words}

J. K. Rowling, Harry Potter, Cormoran Strike, Systemic Functional Linguistics, transitivity system, clause as representation, processes, circumstances, attributes. 


\section{CONTENTS}

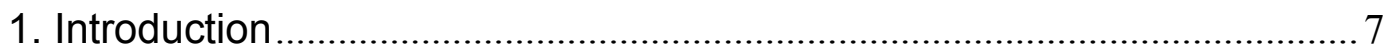

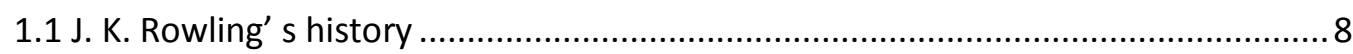

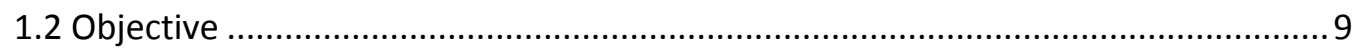

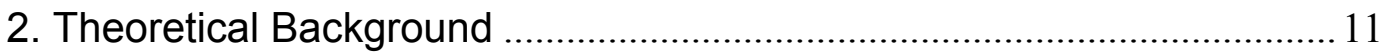

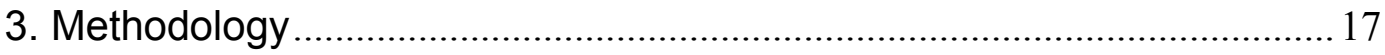

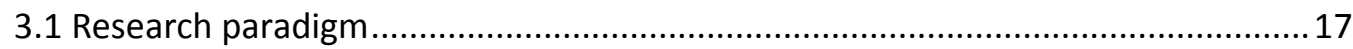

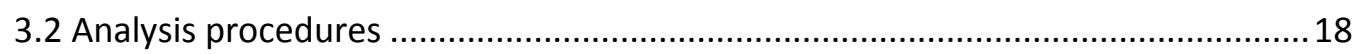

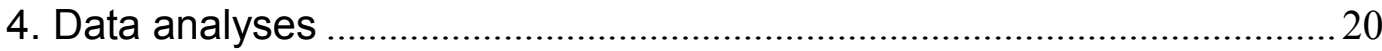

4.1 Excerpts from Harry Potter and Philosopher's Stone ......................................... 20

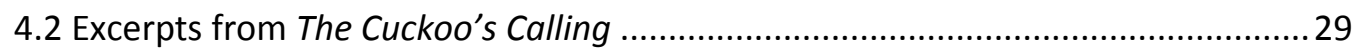

5. Discussion based on lexicogrammar analysis ........................................... 37

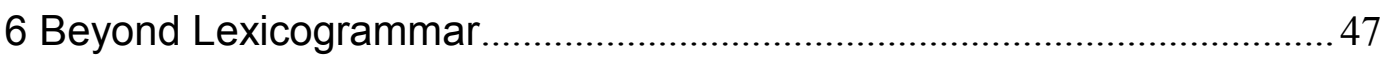

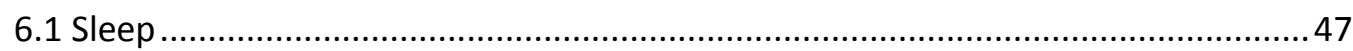

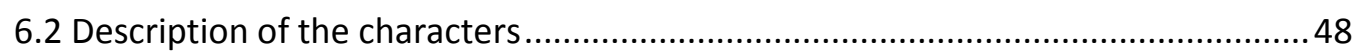

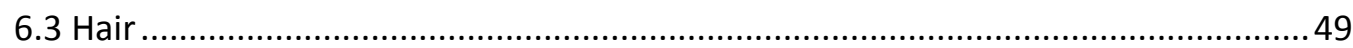

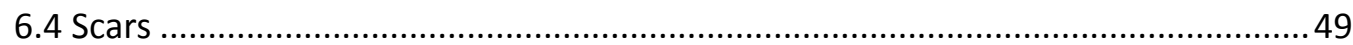

6.5 Orphanhood ......................................................................................... 51

6.6 Characters' state of mind ............................................................................ 51

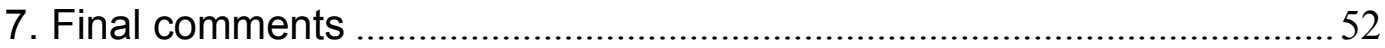

8. References ................................................................................ 53

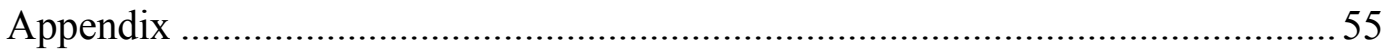

A.1 Harry Potter and the Philosopher Stone ...................................................... 55

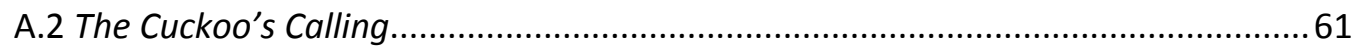




\section{Figures}

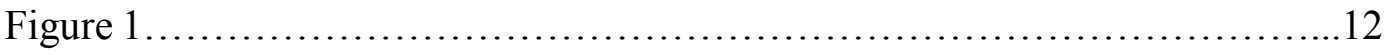

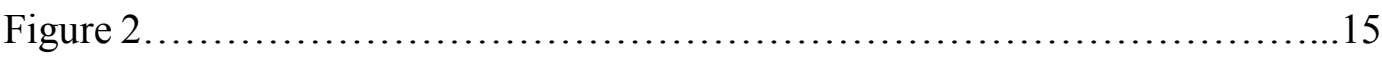

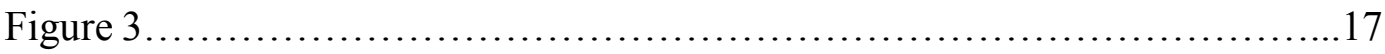

Tables

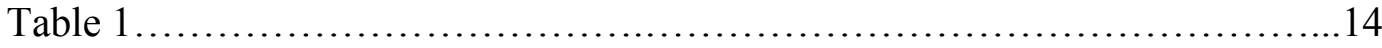

Table 2 .................................................................... 15

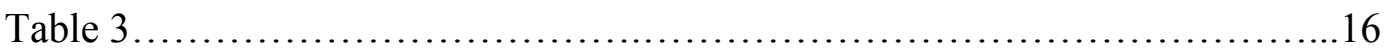

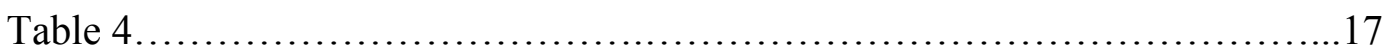

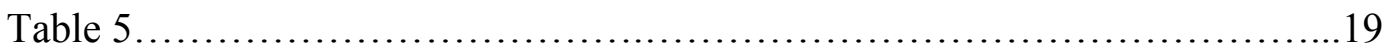

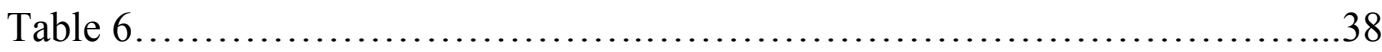

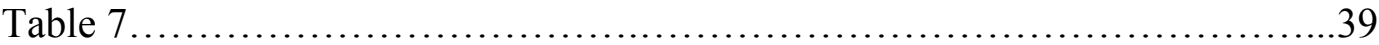

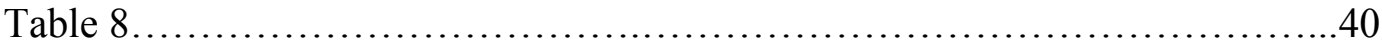

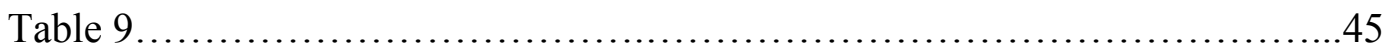

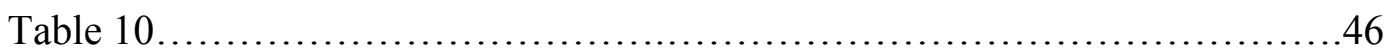




\section{Introduction}

The choice of J. K. Rowling's books as an object of analysis is justified by the richness of the characters she created. Even though her literary production is relatively recent - her first novel was published in 1997 -, her work gives us a broad range of theoretical discussion since the author has produced novels for children and adults and was quite successful with both audiences.

J. K. Rowling is one of the most famous contemporary writers in the world because of the tremendous success of Harry Potter fantasy series. The books were translated into 67 languages, won several awards and sold more de 400 million copies (FLOOD, 2008). She is the first author in the world to make it onto the Forbes Billionaire List (WATSON \& KELLNER, 2004). Her work is also the object of several academic researches and this can be seen on a quick search on Google Academics. When I typed "J.K. Rowling+linguistic analysis", I received approximately 3,500 results. 'When I filtered the results for works written in 2015, I got more than 300 results with broad range of topics, such as: translation, discourse analysis, narrative points of view, genre, representation of gender, characters' identity, stylistic, plot structure etc.

Even though I am an editor of scientific and professional books, I felt the impact of her work on the book industry and the changes it caused in the publishing world. It was very interesting to observe several books of the same genre being published, while all the editors dreamt of finding the "New Harry Potter".

Considering the huge success of this author, the relevance of her work as an object of linguistic research, and the changes the publishing industry has undergone due to her work, as editor, translator, reader and a big fan, I felt the need to look deeper into her work. So I have decided to begin my research analyzing how Rowling builds her heroes. In order to do so, I decided to analyze the lexical choices she made to construe such strong and charismatic protagonists. According to Halliday (2004), Systemic Functional Linguistic (SFL) helps us to understand how meaning is created and expressed (HALLIDAY; and MATHIESSEN, 2004, p. 19)

\footnotetext{
* Available at: $\mathrm{https}: / /$ scholar.google.com.br/scholar?hl=pt$\underline{\mathrm{R} \& \mathrm{q}=\mathrm{J} . \mathrm{K} .+\mathrm{Rowling} \% 2 \mathrm{Blinguistic}+\text { analysis\&btnG}=\& \mathrm{lr}}=$. Accessed in January 2016.
} 
and this was precisely what I wanted. Therefore, I chose to follow this path for my research.

\subsection{J. K. Rowling' s history}

Rowling was born in England in 1965 and studied at Exeter University, where she graduated in French and Classic Studies. She spent one year in France to finish her studies and moved to London as a postgraduate, where she worked as researcher for Amnesty International. Her idea for the Harry Potter series came to her during a delayed train journey from Manchester to London in 1990, but it took her six years to develop the plot for the seven books and write the first novel, Harry Potter and the Philosopher Stone (SHAPIRO, 2007).

J. K. Rowling lived in Portugal, where she taught English, married her first husband and gave birth to her first daughter in 1993. After a divorce, she moved back to the UK to live in Edinburgh, where she struggled to make ends meet and where she finally finished the first novel (SHAPIRO, 2007).

The book was rejected by 12 publishers in the UK (VINCENT, 2012), until she was finally published by Bloomsbury Children's Books in June 1997, under the name J. K. Rowling because her publisher thought that a female writer would not appeal to the target audience of young boys (SHAPIRO, 2007).

I believe that J. K. Rowling has changed the way children and teenagers read, shaping the reading habits and the expectations of a whole generation. She has also broken the paradigm that children/teenagers books are only for this target audience, since many adults - myself included - also became fans of the little wizard.

As I mentioned before, I am an editor, and it was very interesting to witness the major changes the book industry went through due to the huge success of Rowling's books. For instance, as we all know, the bestsellers lists from The New York Times are the most known and well-respected ones in the publishing world. Until July 2000, this list had two main categories: fiction and non-fiction books (BOLONIK, 2000). Children's books rarely even made it to the list. This completely changed with the Harry Potter series. For more than a year, Rowling's books occupied the first three spots of the list (BOLONIK, 2000). When the fourth book was about to be released, The New York Times decided to print a separate list for children's books (BOLONIK, 2000). 
In 2012, J. K. Rowling decided to write for adults. However, the first book for this target audience, The Casual Vacancy, received mixed reviews (BBC, 2012). So, for the second book, The Cuckoo's Calling, she wrote under the pseudonym Robert Galbraith. No one knew who the true writer was and they didn't even know it was written under a pen name. The book was praised by the critics but sold only 1,500 copies (FOX, 2013)

However, after a journalist of The Sunday Times tweeted that the book "didn't seem like the work of a novice", she got an anonymous tweet saying that J. K. had written the book (FOX, 2013). Before confronting Rowling's PR, she decided to make an investigation and found out that The Cuckoo's Calling and The Casual Vacancy were represented by the same literary agent. Then she ordered a forensic linguistic analysis ${ }^{\dagger}$ to compare The Cuckoo's Calling with the works of three female English writers. This analysis showed that the most likely author was Rowling herself (ZAKS, 2014). With all the evidence in hands, The Sunday Time asked directly to Rowling's representatives if she had written the detective novel and they confirmed it. After the news broke, the book reached the first spots in Amazon best-seller list in the USA and the UK (FOX, 2013).

\subsection{Objective}

The purpose of this research is to try to understand how J. K. Rowling builds her heroes. In order to do so, I have chosen to use as data the first two chapters of the author's first published novel, Harry Potter and the Philosopher's Stone, and the first two chapters of her second novel for adult's audience The Cuckoo's Calling.

As a reader, I have already noticed some similarities between these two novels. For instance, both heroes, Harry Potter and Cormoran Strike, are motherless since kids, are somehow famous because of their parents, had troubled childhood, and bare physical scars that they got in some heroic act - Harry Potter has a scar in the forehead, and Cormoran Strike lost a leg during the War in Afghanistan. In terms of narrative, the first chapters do not present us the protagonists as active

\footnotetext{
${ }^{\dagger}$ It is not the purpose of this monograph to discuss this forensic analysis nor its findings. In truth, I am only mentioning this, because this article was my inspiration to come up with my research question.
} 
participants, and there is always a good character that turns out to be the bad guy, or an evil one that you discover that is actually good.

Considering all this, I have decided to analyze both books to try to find out if there could be more similarities than the ones mentioned above. In order to do so, I had to determine how I would begin my analysis since there are several ways to do this. After some thought, I have decided to begin my research with a lower language level - the lexicon - because I am interested in the author's choices of words to depict her heroes. However, this category is too broad, and I had to narrow it down by choosing where I would focus and what theoretical background I would use. Taking all this into account, I have come up with the following research question: Does J. K. Rowling use the same processes, circumstances and attributes to build Harry Potter and Cormoran Strike in Harry Potter and the Philosopher's Stone and The Cuckoo's Calling?"

I believe that this question summarizes the patterns I want to understand and interpret and will make it possible for me to achieve my goal: to understand, from a SFL perspective, the author's linguistic choices to build her heroes regarding the actors and their attributes, the processes they engage and in which circumstances. 


\section{Theoretical Background}

The difference between Traditional Grammar (TG) and Systemic Functional Grammar (SFG) is that while the first focuses more on form, the latter focuses more on meaning. It is called "systemic" because it considers language as a set or interconnected linguistic systems and "functional" because it explains the grammatical structures in relation to meaning (FUZER; CABRAL, 2014, p. 19). SFG focuses on the study of language in use in a given social context and this happens because language is something alive used by people in different situations, places and events and, thus, it is influenced by these factors. In order to establish relations and satisfy their needs in a specific social context, the users of a language choose from a range of possibilities available (FUZER; CABRAL, 2014).

For SFL, language is a stratified system with each interconnected strata representing a level of abstraction: context, semantics, lexicogrammar, and phonology (Figure 1).

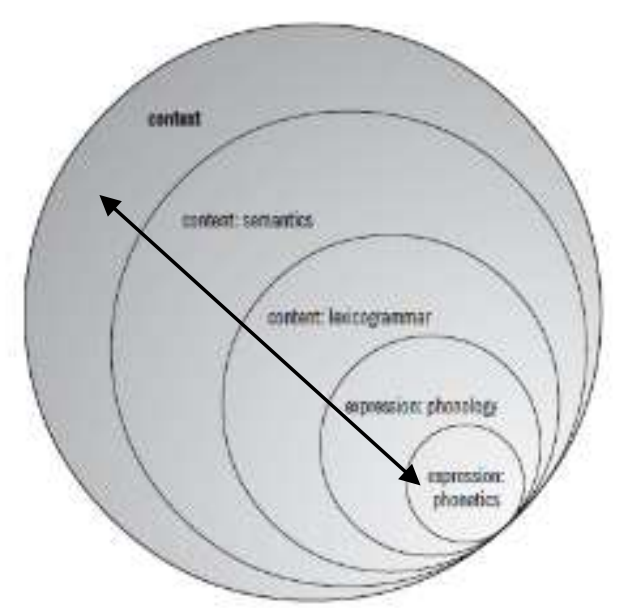

Figure 1. Stratification (adapted from HALLIDAY; MATHIESSEN, 2004, p. 25 and FUZER; CABRAL, 2014, p. 22).

For this research, I will focus on lexicogrammar aspects, since I have chosen to work with processes, circumstances and attributes. However, even though I will be focusing on a lower level when analyzing excerpts from the books, I cannot

I have translated the quotations from Fuzer's and Cabral's text as well as the ones from Vian Jr.'s text. 
disregard the text as a whole since they are the "instantiation of the linguistic system" (VIAN JR., 2014, p. 423) and the excerpts are part of a context.

According to SFL, each text has a specific communicative goal that takes into account the context in which it is produced. There are two kinds of context: context of culture and context of situation. The context of culture is more comprehensive and comprises extra-linguistic factors such as social conventions, beliefs, values and institution (FUZER; CABRAL, 2014, p. 26, 28). Since I am interested in a lower language level - the lexicogrammar stratum (see Figure 1 above) -, I will not focus on the context of culture here nor on the influence it might have on my analysis.

The context of situation - or register - is a kind or micro-context, which is closer to the text. It comprises three variables: field of activity, which is the nature of the social activity realized by the participants (FUZER; CABRAL, 2014, p. 30); tenor of activity, the participants and their relations in terms of social distance (status, politeness, formality); and mode of activity, how the production is going to reach the intended audience (oral text, written text or non-verbal).

One other aspect of SFL that co-relates with context of situation is the three metafunctions: Ideational, that has to do with meaning, interpersonal, which is the relation among participants; and textual that relates to the organization of the text itself. For each metafunction, there is a different system for analysis because the lexicogrammar realization is different. This happens because each linguistic component in a same sentence can be interpreted in different ways (multifunctionality). Table 1 below summarizes the context of situation in the books I will analyze for this paper and their respective metafunction.

The ideational metafunction is used to express our experience in the material world (outer experience), or in our interior world (inner experience). Since I intend to analyze processes, circumstances and attributes, I will concentrate on this metafunction.

The ideational metafunction is divided into logic metafunction and experimental metafunction. The system of transitivity is where the experimental meaning manifests itself. Different from the TG, in which transitivity is the relation between the verb and its complements, in the SFG, it is the relation among all the components of the clause to form a figure. A figure, or a configuration of a process, is the meaning of the processes in association with the participants and in some 
Table 1. Description of context of situation in Harry Potter and the Philosopher's Stone and The Cuckoo's Calling

\begin{tabular}{|c|c|c|}
\hline Context of situation & $\begin{array}{l}\text { HP and the Philosopher's } \\
\text { Stone }\end{array}$ & The Cuckoo's Calling \\
\hline $\begin{array}{l}\text { Field of activity } \\
\text { (ideational metafunction) }\end{array}$ & $\begin{array}{l}\text { A fantasy book for children } \\
\text { and young adults in which } \\
\text { an eleven-year old boy } \\
\text { finds out that he is a wizard } \\
\text { and is enrolled in a school } \\
\text { for wizards. }\end{array}$ & $\begin{array}{l}\text { A mystery book in which a } \\
\text { private investigator is } \\
\text { hired to investigate the } \\
\text { death of a famous } \\
\text { supermodel that was } \\
\text { considered a suicide by the } \\
\text { police. }\end{array}$ \\
\hline $\begin{array}{l}\text { Tenor of activity } \\
\text { (interpersonal } \\
\text { metafunction) }\end{array}$ & $\begin{array}{l}\text { Author of books for } \\
\text { children and young adults } \\
\text { readers. } \\
\text { Maximum social distance } \\
\text { between the author and her } \\
\text { target audience. She told } \\
\text { the story in a given } \\
\text { moment and the audience } \\
\text { reads whenever they want, } \\
\text { wherever they want and } \\
\text { how many times they want. }\end{array}$ & $\begin{array}{l}\text { Author of books for adults } \\
\text { readers. } \\
\text { Maximum social distance } \\
\text { between the author and her } \\
\text { target audience. She told } \\
\text { the story in a given } \\
\text { moment and the audience } \\
\text { reads whenever they want, } \\
\text { wherever they want and } \\
\text { how many times they } \\
\text { want. }\end{array}$ \\
\hline $\begin{array}{l}\text { Mode of activity (textual } \\
\text { metafunction) }\end{array}$ & $\begin{array}{l}\text { A creative narrative } \\
\text { realized in a monolithic } \\
\text { written text published as a } \\
\text { book and sold in both } \\
\text { paperback and hardcover. }\end{array}$ & $\begin{array}{l}\text { A creative narrative } \\
\text { realized in a monolithic } \\
\text { written text published as a } \\
\text { book and sold in both } \\
\text { paperback and hardcover. }\end{array}$ \\
\hline
\end{tabular}

(Adapted from FUZER; CABRAL, 2014, p. 31)

cases the circumstances. It is important to say that the processes are always the central element of the clause and the "participants are close to the center [because] they are directly involved in the process" (HALLIDAY; MATHIESSEN, 2004, p. 176) (see Figure 2 in the next page). For this paper, I will only consider processes related to the participants Harry Potter in Harry Potter and the Philosopher Stone and Cormoran Strike in The Cuckoo's Calling.

Processes are actions and can be divided into material, mental and relational (primary processes) and existential, verbal and behavioral (secondary processes). The material process is "the representation of external experiences" (FUZER; CABRAL, 2014, p. 43) involving one or two participants and can be divided into two types: creative or transformative. The participants receive different names 

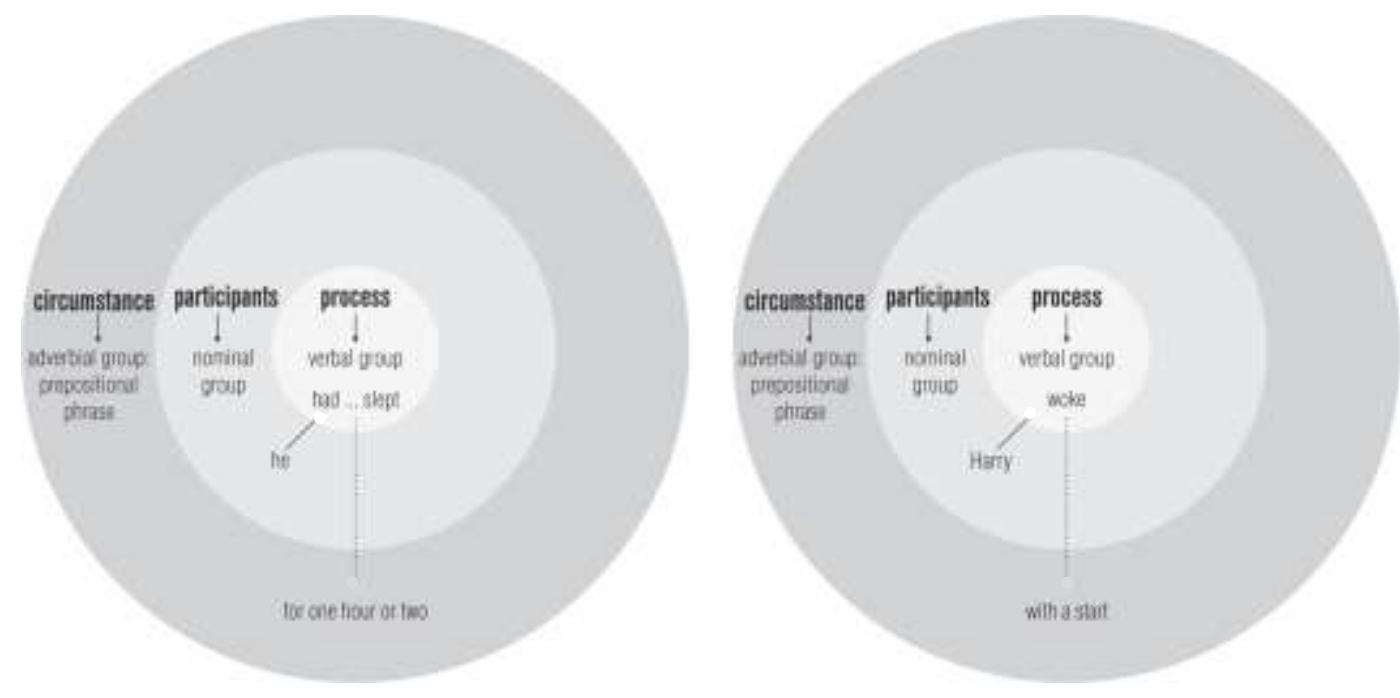

Figure 2. Central and peripheral elements in the experiential structure of a clause (adapted from HALLIDAY; MATHIESSEN, 2004, p. 176)

depending or their role. Actor is the participant who performs the process; goal is the one affected by the process; scope is the participant not affected by the process and beneficiary the one who receives something. The mental process is "the representation of internal experiences" (FUZER; CABRAL, 2014, p. 43) and process and beneficiary the one who receives something. The mental process is "the representation of internal experiences" (FUZER; CABRAL, 2014, p. 43) and is divided into four types: perceptive (involving one of the five senses), cognitive (thoughts), emotive (feelings), desiderative (desires). Since the process is something experienced by the participant, this agent is called senser and the complement of the process is called phenomenon. The relational process is the representation of relations between two different entities. These are the processes of being and having. They are divided into three types: intensive (characterizing an entity), possessive (ownership relation), circumstantial (relation with time, place, cause etc.). These three types can present two different modes: attributive and identifying. Table 2 below shows examples of primary process types form both books.

The secondary processes are located at the boundaries of the primary processes (HALLIDAY; MATHIESSEN, 2004, p. 171). The behavioral process is between the mental and the material processes and represents "physiological and 
Table 2. Examples of different primary process types from Harry Potter and the Philosopher Stone and The Cuckoo's Calling

\begin{tabular}{|l|l|}
\hline Process type & Example (process in bold; participants underlined) \\
\hline Material & "Harry moved in front of the tank..." (ROWLING, p. 25) \\
\hline Mental & "But he wished, he hadn't said anything." (ROWLING, p. 24) \\
\hline Relational & "Her accidental assailant was massive." (GALBRAITH, p. 19) \\
\hline
\end{tabular}

(Adapted from HALLIDAY; MATHIESSEN, 2004, p. 171)

psychological behaviors" (HALLIDAY; MATHIESSEN, 2004, p. 248) such as sleeping, yawning, dancing, coughing, smiling, dreaming etc. The participants in these processes are called behaver and the complement involved is the behavior. The verbal processes are between the relational and the mental processes and are the representation of what a participant says. This type of process makes it possible to reproduce dialogues in narrative texts and gives voice to other participants in journalistic texts, academic papers etc. The participants in this process are called sayer and target (when they are directly involved) or receiver and verbiage (when they are obliquely involved). The last secondary process is the existential process, which is between the material and relational processes. It is "the representation of something that happens or exists" (FUZER; CABRAL, 2014, p. 78). In this kind of process, there is no subject in the sentence and its participant is called existent, which can be represented by "a person, an object, an institution or an abstraction, as well as an action or event" (FUZER; CABRAL, 2014, p. 79). Table 3 below shows examples of primary process types form both books.

Table 3. Examples of different secondary process types from Harry Potter and the Philosopher Stone and The Cuckoo's Calling

\begin{tabular}{|l|l|}
\hline Process type & Example (process in bold; participants underlined) \\
\hline Behavioral & $\begin{array}{l}\text { "Strike absorbed the impact, heard the high-pitched scream and reacted } \\
\text { instinctively" (GALBRAITH, p. 18) }\end{array}$ \\
\hline Verbal & $\begin{array}{l}\text { "'I'm not going to do anything,' said Harry, 'honestly'." (ROWLING, p. } \\
\text { 23) }\end{array}$ \\
\hline Existential & "There were no photographs of them in the house" (ROWLING, p. 27) \\
\hline
\end{tabular}
(Adapted from HALLIDAY; MATHIESSEN, 2004, p. 171)

Even though the processes are ordered, there is no relation of priority of one kind over the other. Actually, they can be best represented in a circle as shown in Figure 3 , with borders that are not definitive and static but rather "continuous and shading into one another" (HALLIDAY; MATHIESSEN, 2004, p. 172). 


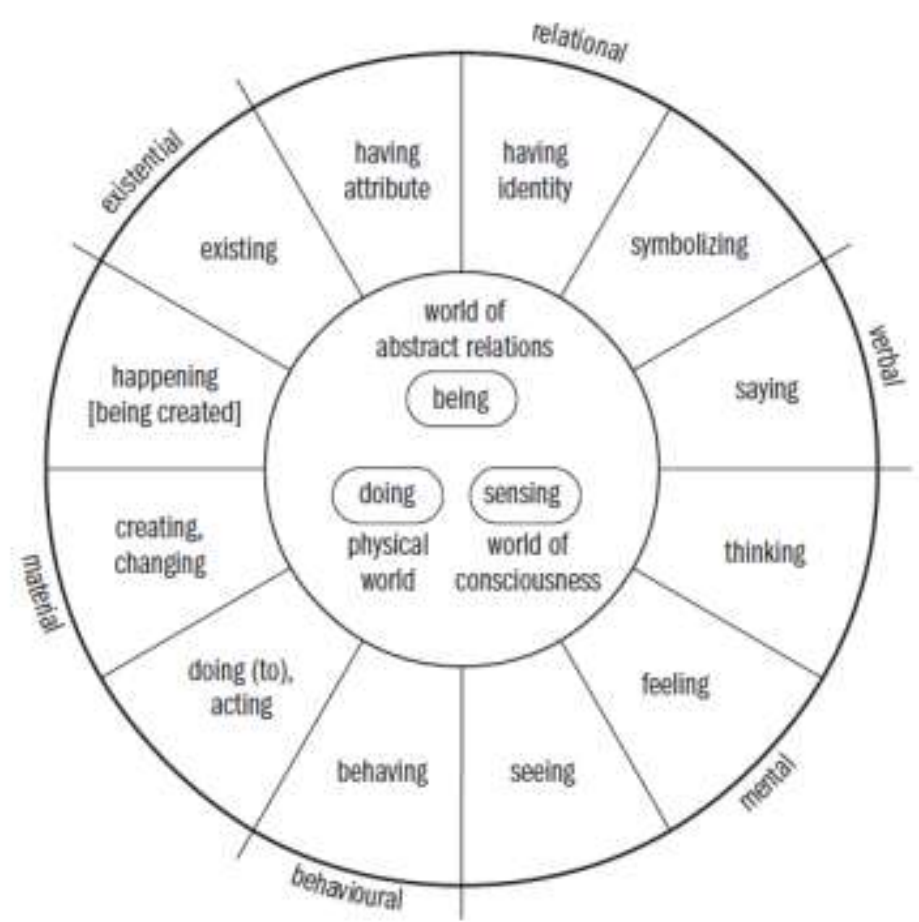

Figure 3. Types of process (from HALLIDAY; MATHIESSEN, 2004, p. 172).

Circumstances add meaning to the processes through the definition of extent, location, manner, cause, contingency, accompaniment, role, matter and angle. Their presence in a clause is not mandatory but rather an optional addition (HALLIDAY; MATHIESSEN, 2004, p. 175), they are further away from the center of the clause - the process (see Figure 2 above) and they are not directly involved in the process.

Attributes introduce the participants' characteristics and are usually present in relational clauses. However, they can also be present in material clauses, in which case they can be of two types: resultative - to show the result for the actor or the goal after a process is concluded; or descriptive - to show the state of the actor or the goal when they take part of a process.

Table 4. Examples of attributes from The Cuckoo's Calling

\begin{tabular}{|l|l|}
\hline Process & Example from the books (processes in bold and attributes in italics) \\
\hline Relational & "One of his eyes was puffy and bruised." (GALBRAITH, p. 25) \\
\hline Material & \\
\hline Resultative & "...his humiliation was laid bare" (GALBRAITH, p. 23) \\
\hline Descriptive & "He submerged his throbbing head" (GALBRAITH, p. 20) \\
\hline
\end{tabular}




\section{Methodology}

"Document analysis is a systematic procedure for reviewing or evaluating documents" (BOWEL, 2009, p. 27) in order to develop understanding. This research will consist of a documental analysis of excerpts from two novels by J. K. Rowling, Harry Potter and the Philosopher's Stone and The Cuckoo's Calling, with the purpose of understanding how this author builds her heroes.

In the subsections below, I will describe how I organized my research and how I made the selection of excerpts in order to carry out my investigation.

\subsection{Research paradigm}

When analyzing a narrative, there is no absolute truth to be found but rather an open interpretation of the reality created by the author. Constructivists tend to be antifoundational, since they do not believe that there is a fixed or permanent standard by which the "truth can be universally known" (GUBA; LINCOLN, 2011, p. 177). My quest here is not to find an undeniable truth, but to try to understand how this author was able to build such strong and charismatic protagonists. Therefore, I cannot use any other paradigm but the constructivist (ibid.) interfaced with a qualitative approach.

I will not attempt to present a hypothesis to either validate it or give it a solution, like a positivist or a post-positivist researcher would. My aim here is to interpret the data from a systemic functional perspective. Of course, my choices will be subjective and influenced by my background not only as a reader and a fan, but also as an editor and a translator. According to Guba and Lincoln (2011), "the meaning-making activities themselves are of central interest to social constructivists/constructivists, simply because it is the meaning-making/sensemaking/ attributional activities that shape action (or inaction)" (ibid., p. 167).

My research is focused on a contextualized and personal experience as a reader of both books and a fan of the author. This means that my interpretation and my voice will be present throughout the whole analysis. It is obvious to me that should it be another researcher doing this work, the excerpts and the interpretation would be different as well as the conclusions he/she might come up with.

Even though this is a qualitative research, I felt it was necessary to present some quantitative data to help me to enlighten my findings. 


\subsection{Analysis procedures}

In order to make a document analysis (BOWEL, 2009) of both novels, I will choose some excerpts in which the protagonists - Harry Potter and Cormoran Strike - are the main participants to analyze the author's linguistic choices regarding processes, circumstances and attributes. In the subsections below, I will describe how the data was selected and analyzed.

\subsubsection{Data selection}

Since I am interested in understanding how J. K. Rowling builds her protagonists, I have chosen excerpts from chapters 1 and 2 of both books. All the chosen excerpts are transcribed in the Appendix in the end of this paper, and each one of them was tagged with an alphanumeric code such as HP-1, HP-2 and so on for excerpts from Harry Potter and the Philosopher's Stone and CS-1, CS-2 etc. for the ones from The Cuckoo's Calling.

Even though I will only analyze the excerpts from those pages, as a qualitative researcher I may choose some excerpts from other chapters that enlighten my findings and which may be relevant for the discussion section and conclusion of this paper.

\subsubsection{Analysis criteria}

As I mentioned in the subsection above, each excerpt is transcribed in the appendix and has been marked according to Table 5 below.

Table 5. Guide for the analysis

\begin{tabular}{|l|l|}
\hline Type & Marking \\
\hline Material process & Bold and simple underline \\
\hline Mental process & Bold and italics \\
\hline Relational process & Bold \\
\hline Verbal process & Bold, italics and double underline \\
\hline Behavioral & Bold italics and dotted underline \\
\hline Existential & Bold and dotted underline \\
\hline Attributes & Italics \\
\hline Circumstances & $\begin{array}{l}\text { Simple underline (only the subcategories quality and degree of } \\
\text { circumstantial elements of manner) }\end{array}$ \\
\hline
\end{tabular}


In chapter 4, I selected some of the chosen excerpts transcribed and marked in the Appendix to be analyzed and discussed according to the lexicogrammatical elements in which I am interested.

After this, even though this is qualitative research, I felt the need to present some quantitative data in chapter 5 in order to have a better understanding of how Rowling built her protagonists. So, I made correlations and comparisons between both books, taking into account the analysis on chapter 4 and the quantitative data presented in chapter 5 .

Finally, in chapter 6, I present a brief interpretation of my findings going beyond lexicogrammar and using a semantic point of view.

All the markings and emphasis added in the excerpts in subsections 4.1.1 and 4.1.2 and the appendix are mine. All the emphasis used by the author were omitted in those subsections for the sake of analysis. I would also like to emphasize that I only analyzed the processes, circumstances and attributes related to the participant Harry Potter in Harry Potter and the Philosopher Stone and the participant Cormoran Stike in The Cuckoo's Calling.

Lastly, I would like to mention that, according to Halliday e Mathiessen (2004), the boundaries of behavioral processes are not easy to identify because they are fuzzy. There are behavioral processes that are "near mental" (such as, hear, see, stare), "others that are near verbal" (such as, murmur, mouth, grumble), and others that are "near material" (such as laugh, smile, sit down, lie down, etc.) (HALLIDAY; MATHIESSEN, 2004, p. 251). 


\section{Data analysis}

As I mentioned before, as a reader I have already noticed some similarities between these two novels. I believe that these similarities might be deeper than they appear to be at a first sight. The aim of this research is to understand how the author builds her characters - considering that the books are for different target audiences - and try to find similarities in the way she does so by analyzing her choices of words from a systemic functional perspective.

In this chapter, I will select some of the chosen excerpts transcribed in the Appendix (already marked according to Table 5) and analyze J. K. Rowling's choices of processes, circumstances and attributes to build her protagonists so that, based on this analysis, I can build my own analytical interpretation.

\subsection{Excerpts from Harry Potter and Philosopher's Stone}

\section{- HP-1 - Harry Potter's introduction as a baby}

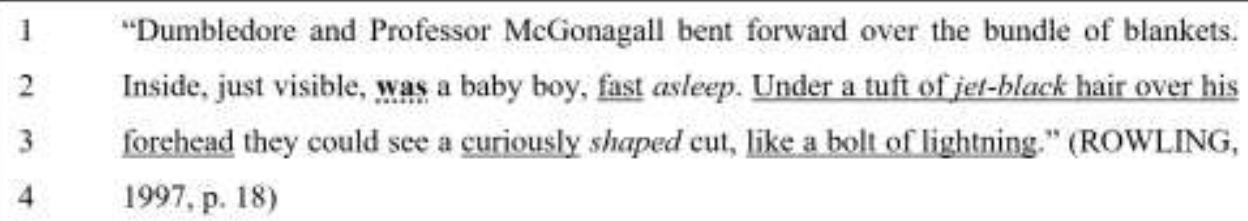

This excerpt is from the scene in which Dumbledore leaves Harry in the doorsteps of this aunt's house. I have chosen it because it shows how J. K. Rowling introduces our hero in the story: using an existential clause (line 2), followed by an attribute, "asleep" (line 2), modified by the circumstance "fast" (line 2). I think it is fascinating that J. K. Rowling has chosen to introduce Harry with an existential clause (line 2) almost as a statement saying that he exists. Another interesting (and surprising) element is that in the very first appearance of the protagonist, he is "fast asleep" (line 2).

The first glimpse the readers have regarding the protagonist's appearance is presented in lines 2 and 3 through other people's eyes (Dumbledore and Professor McGonagall). The author here gives two distinguishing characteristics: the hair and the scar. His hair is not only black, but "jet-black" (line 2). It seems here that the author felt the need to use a stronger epithet to show that Harry's hair was blacker than expected. 
Another important information regards the scar he received on his forehead (line 3) when Voldermort tried to kill him and did not succeed. Again, Rowling shows in a quite simple way that it is not a scar like any other. By choosing a circumstantial element of manner, "curiously" (line 3), to qualify the attribute "shaped" (line 3) and then another one to stablish a comparison, "like a bolt of lightening" (line 3), she is able to evoke a very vivid image and, at the same time, to convey to the readers that Harry's scar is somewhat special, is in a place where everyone can see, and which distinguishes him from others.

\section{- HP-2 - Baby Harry still sleeping}

\begin{tabular}{|ll|}
\hline 1 & "Harry Potter rolled over inside his blankets without waking up. One small \\
2 & hand closed on the letter beside him and he slept on, not knowing he was \\
3 & special, not knowing he was famous, not knowing he would be woken in a \\
4 & few hours' time by Mrs. Dursley's scream as she opened the front door to put \\
5 & out the milk bottles, nor that he would spend the next fow weeks being \\
6 & prodded and pinched by his cousin Dudley..." (ROWLING, 1997, p. 18)
\end{tabular}

This excerpt is from the same scene as HP-1 above and brings a lot of clues to an attentive reader. Here, we see some material processes - "rolled over" (line 1) and "closed" (line 2), "waking up" (line 1) - followed by a behavioral one, "sleep on" (line 2), indicating that he is still asleep, oblivious to the fact that his life is about to change. To reinforce this idea, Rowling used a combination of a mental clause, "not knowing", with a relational one, "was", twice (lines 2 and 3) to introduce two very important attributes that are intrinsically related to Harry Potter throughout not only this book but also the whole series: he is "special" and he is "famous" (line 3). She could have used a simple relational clause to state that but she has chosen to add a mental one, giving more flavor and style to the text, and also informing that he does not know, and probably won't know for a long time. Then, she uses the same combination "know + be" (line 3) adding two material processes, "wake up" and "spend", (lines 3 and 5) to indicate to the readers that Harry will not be lovingly received by his relatives. Instead, he will screamed at as the circumstantial element in line 4 shows and bullied by his cousin (lines 5 and 6) as the material processes "prodded" and "pinched" convey. 


\section{- HP-3 - Harry Potter's introduction as a boy}

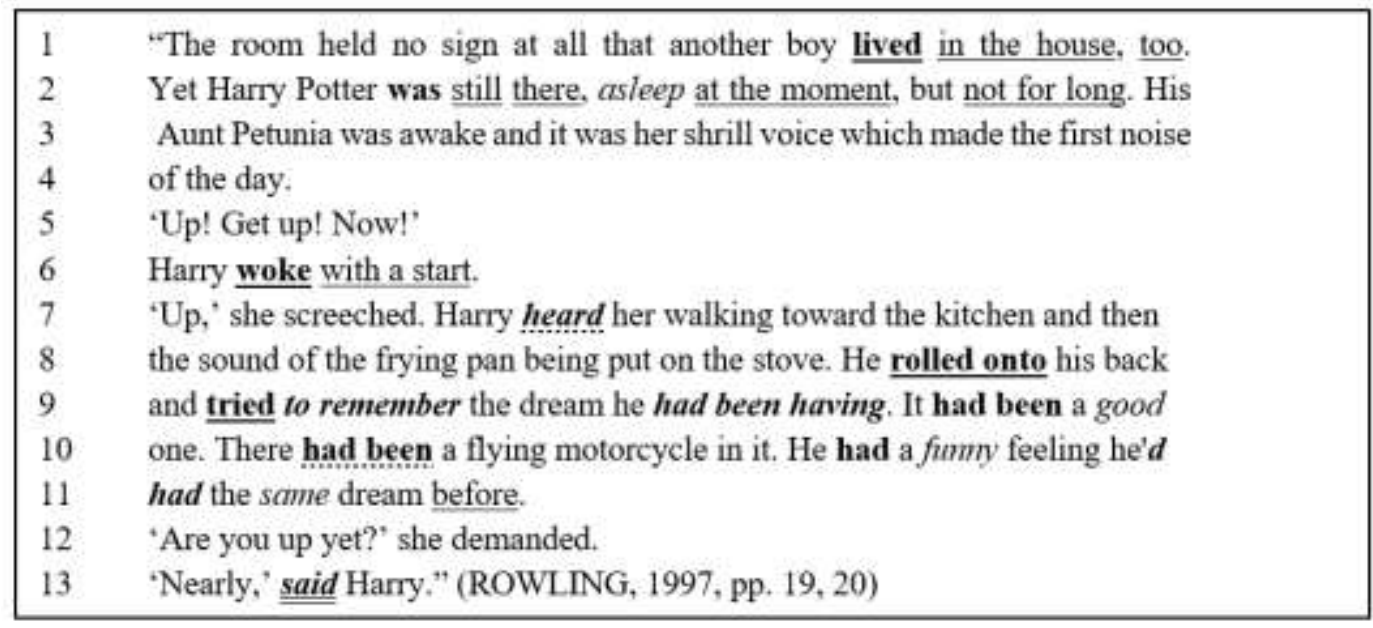

This excerpt is from the beginning of the second chapter and gives the reader many clues to what might have happened in the time that passed between chapters 1 and 2 and to what may happen in the near future.

Line 1 reinforces the clue we found on excerpt HP-2, lines 4 to 6, that Harry's relatives did not welcome him to the family. To show this, Rowling used a material process, "live" (line 1) and a circumstantial element of location "in the house" (line 1) and one of extent, "too" (line 1).

In line 2, Rowling uses a relational process ("be") followed by a circumstantial element of place ("there") emphasized by a circumstantial element of time ("still") to enhance that even though there is no sign of another boy's presence in the house (line 1), Harry is at the same place he was almost 11 years ago. This is further emphasized by the fact that he is asleep, exactly the same attribute the author used in HP-1 (line 2) to introduce the character, giving the reader a sensation of continuity. For me, it is as if the author wants to convey that Harry's life during the almost 11-year period in which he was living with his uncles was a repetition of events: sleeping, being waken up by his aunt's screams and being constantly abused in a vicious circle. Excerpts HP-4, HP-6, HP-7 - which will not be discussed in details here - further reinforce this because they describe Harry's routine.

Line 2 gives the readers yet another clue with the circumstantial element of duration "not for long". For me, this is a sign that things are about to change. Line 6 also has a clue to what might happen, again through the circumstantial element of manner "with a start". Among all the choices the author could have made in the 
paradigmatic order, such as "startled", "alarmed", "suddenly" etc., to describe how he woke up, she has chosen the expression "with a start". "Start" also means "beginning" and I believe that this is a sign to indicate that the story is about to begin. And here, I would like to use Halliday's own words: "A language is a resource for making meaning, and meaning resides in systemic patterns of choices" (HALLIDAY and MATHIESSEN, 2004, p. 23)

Lines 7 to 13 are very rich, bringing all types of processes: behavioral ("hear, line 7), material ("roll" and "try", lines 8 and 9 respectively), mental ("remember", line 9; "have"[a dream], lines 9 and 11), existential (line 10), relational ("have", line 10) and verbal ("say", line 13). These lines also brings three attributes related to his dream ("good", line 9; "funny", line 10; and "same" line 11) and one circumstance of time ("before", line 11) also related with his dream. As we could see here, the author used all the elements I am analyzing in seven sentences in a row! This shows how Rowling use different processes to contrast what's going on in the outside world (outer experience) and inside the character (inner experience). Harry hears what is happening outside his cupboard (line 7) but he wants to remember his good dream (line 9), the one he thinks he had before (line 11).

\section{- HP-5 - Harry's physical appearance}

\begin{tabular}{|ll|}
\hline 1 & "Dudley's favorite punching bag was Harry, but he couldn't often catch \\
2 & him. Harry didn't look it, but he was very fast. \\
3 & Perhaps it had something to do with living in a dark cupboard, but Harry \\
4 & had always been small and skinny for his age. He looked even smaller and \\
5 & skimnier than he really was because all he had to wear were old clothes of \\
6 & Dudley's, and Dudley was about four times bigger than he was. Harry had a \\
7 & thin face, knobbly knees, black hair, and bright green eyes. He wore round \\
8 & glasses held together with a lot of Sellotape because of all the times Dudley \\
9 & had punched him on the nose. The only thing Harry liked about his own \\
10 & appearance was a very thin scar on his forehead that was shaped like a bolt \\
11 & of lightning. He had had it as long as he could remember, and the first \\
12 & question he could ever remember asking his Aunt Petunia was how \\
13 & he had gotten it." (ROWLING, 1997, pp. 20)
\end{tabular}

This whole excerpt is about Harry's physical appearance. As expected, there are many relational processes (lines 2, 4, 5, 6, 10, 11 and 11), and attributes (lines 2, 4, 5, 7 and 10). However, there are also material (lines 3, 5 and 13), verbal (line 12) and mental (lines 9 and 11) processes, making the description much richer and engaging. It is also interesting to see how the author uses another character's 
(Dudley's) physical appearance and behavior to create, by contrast, an image of the protagonist (line 6).

In line 10, Rowling uses the emotive mental process "like" to show the readers how Harry felt about his appearance - he only likes his scar, which again is characterized with the same circumstantial element of comparison, "like a bolt of lightning" (lines 10 and 11), she used in HP-1 line 3. However, this time she added another element, using a circumstantial element of degree, "very", and an attribute, "thin" (line 10). Rowling also uses the scar to introduce, in a subtle way, yet another characteristic of our protagonist using the verbal process "ask" (line 12). Even though Harry is "forbidden to ask questions" (HP-17, line 13) - "Don't ask questions - that was the first rule for a quiet life with the Dursleys" (ROWLING, 1997, p. 20) -, he asks a lot of questions, as we can see in "questions exploded inside Harry's head like fireworks and he couldn't decide which to ask first" (ROWLING, 1997, p. 43); he feels "he'd never had so many questions in his life" (ROWLING, 1997, p. 51)

The author gives us another interesting clue using a relational process ("look", lines 2 and 4) to inform the readers that Harry is not what he seems: He does not seem but he is not only fast, but "very fast" (line 2); and he isn't as small and skinny as he seems (lines 4 and 5). What underlies here, in my opinion, is that even though it doesn't look like he is special he actually is.

In addition to his physical appearance, in the short excerpt above the author informs once again how abusive the Dursleys were: Harry was bullied by his cousin who punched him in the face (line 8 ), and by his uncles, who only gave him Dudley's old clothes to wear (lines 4 and 5).

\section{- HP-16 - Strange things}

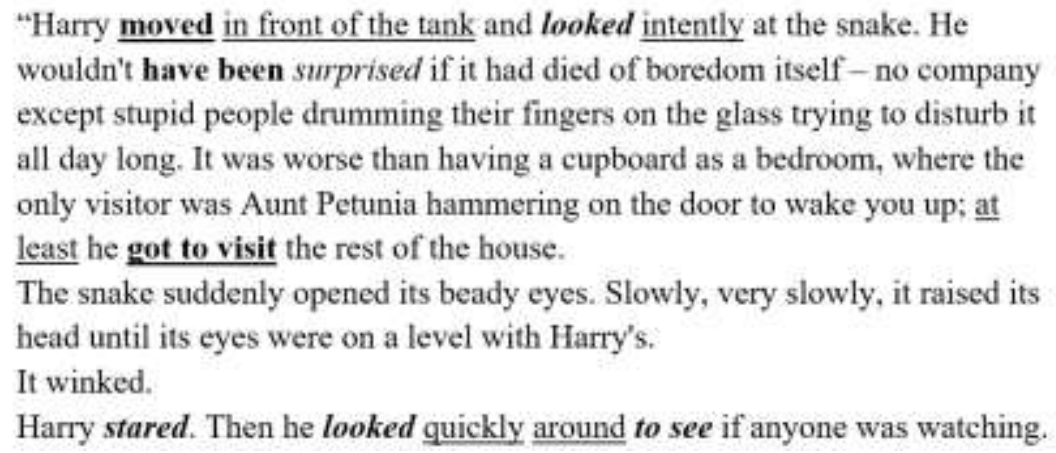


They weren't. He looked back at the snake and winked, too.

The snake jerked its head toward Uncle Vernon and Dudley, then

raised its eyes to the ceiling. It gave Harry a look that said quite plainly:

'I get that all the time.'

'I know', Harry murmured through the glass, though he wasn't sure the snake could hear him. 'It must be really annoying.'

The snake nodded vigorously.

'Where do you come from, anyway?' Harry $\underline{\underline{\text { asked. }}}$.

The snake jabbed its tail at a little sign next to the glass. Harry peered at it.

Boa Constrictor, Brazil.

'Was it nice there?'

The boa constrictor jabbed its tail at the sign again and Harry read on:

This specimen was bred in the zoo. 'Oh, I see - so you've never been to

Brazil?'

As the snake shook its head, a deafening shout behind Harry made both of

them jump.

'DUDLEY! MR. DURSLEY! COME AND LOOK AT THIS SNAKE!

YOU WON'T BELIEVE WHAT IT'S DOING!'

Dudley came waddling toward them as fast as he could.

'Out of the way, you,' he said, punching Harry in the ribs. Caught by

surprise, Harry fell hard on the concrete floor. What came next happened so

fast no one saw how it happened - one second, Piers and Dudley were

leaning right up close to the glass, the next, they had leapt back with howls

of horror.

Harry sat up and gasped; the glass front of the boa constrictor's tank had vanished. The great snake was uncoiling itself rapidly, slithering out onto the floor. People throughout the reptile house screamed and started running for the exits.

As the snake slid swiftly past him, Harry could have sworn a low, hissing voice said, 'Brazil, here I come.... Thanksss, amigo.' (ROWLING, 1997, pp. 25, 26)

In excerpts HP-12 and HP-13 (see the Appendix in the end of this paper), the author tells the reader about strange things that have happened to Harry. In this excerpt, however, the narrator describes one strange event as it happens, giving information about the hero's feelings and thoughts during the description.

The scene begins with a material process ("move", line 1) and a circumstantial element of place ("in front of the tank", line 1), followed by a mental process ("look") and another circumstantial element, but this time of degree, "intently" (line 1). I think that this last circumstantial element is the most important information in this sentence. Harry is at the zoo and he is supposed to look at the animals. However, how he looks at the snake is what it important here. He looks at it "intently", which means full of intention. Considering the paradigmatic order (HALLIDAY and MATHIESSEN, 2004, p. 22), this choice is quite interesting. She could have chosen "attentively", "with attention", "with interest" and so on, that is how people usually look at animals at the zoo. I believe that her choice is full of 
intention conveying that Harry behaves differently from other people. Right after this sentence, we see a relational process (line 2) followed by an attribute ("not surprised", line 2), conveying, with comes next (lines 2 to 6), that Harry is, somehow, relating to that snake - which is something strange -, and concluding that his life is a little better than the snake's, using a circumstantial element ("at least", line 6) and material process ("visit", line 6).

From lines 7 to 9, the narrator describes an unusual behavior for a snake and, in line 10, Harry is the senser of three mental process in a row ("stare", "look" and "see") indicating that Harry knows that the snake's behavior is strange. Then, we have another mental process ("look", line 11) followed by a material one ("wink", line 11) and a circumstantial element ("too, line 11), conveying that Harry's behavior is as strange as the snake's.

From lines 14 to 25 , there is a dialogue between the snake and Harry. In line 15 , Harry answers with a mental clause - "I know" - followed by a verbal process ("murmured") and a circumstantial element of manner ("through the glass). In the beginning of the dialogue, there is a relational attributive clause "though he wasn't sure" (line 15), showing that Harry is not convinced that the snake was indeed hearing him, but answering to it nonetheless. I believe that this might be an indication that Harry is a curious boy, with an open mind to accept different things, even when he cannot explain them.

When the snakes respond to his comment with a vigorous nod (line 17), we see another verbal process ("ask", line 18) and the snake answers with a sign. The author uses a mental process ("peered", line 19) to indicate that Harry read the answer and in the next time the snake answers, Rowling chose to use a material process ("read", line 22). Harry then answer with a mental process ("see", line 23), followed by another question. After this, they are interrupted by a scream, and they react with a material process (“jump", line 26).

In lines 27 to 30 , there is yet another display of how Harry is treated by the Dursleys and their friends. A material process ("catch", line 30) followed circumstantial element of manner ("by surprise", lines 30 and 31) convey that Harry was totally focus on the snake and was not aware of his surroundings. Duddley punches Harry who "falls hard" (material process +manner circumstance, line 31 ). Harry's next action is described with a material process ("sit", line 35), followed 
by a behavioral one ("gasp", line 35), indicating that he is surprised with the disappearance of the glass.

The mental clause ("could have sworn", line 39) that closes the excerpt, indicates that Harry is not affirming he heard, but that he thinks he heard. I believe that this a way the author found to convey that Harry heard the snake but thinks something like that would be impossible.

\section{- HP-17 - Harry's thoughts}

\begin{tabular}{|c|c|}
\hline 1 & 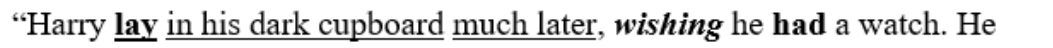 \\
\hline 2 & didn't know what time it was and he couldn't be sure the Dursleys were \\
\hline 3 & asleep yet. Until they were, he couldn't risk sneaking to the kitchen for \\
\hline 4 & some food. \\
\hline 5 & He'd lived with the Dursleys almost ten years, ten miserable years, as long \\
\hline 6 & as he could remember, ever since he'd been a baby and his parents had died \\
\hline 7 & in that car crash. He couldn't remember being in the car when his parents \\
\hline 8 & had died. Sometimes, when he strained his memory during long hours in his \\
\hline 9 & cupboard, he came up with a strange vision: a blinding flash of green light \\
\hline 10 & and a burning pain on his forehead. This, he supposed, was the crash, \\
\hline 11 & though he couldn't imagine where all the green light came from. He \\
\hline 12 & couldn't remember his parents at all. His aunt and uncle never spoke about \\
\hline 13 & them, and of course he was forbidden to ask questions. There were no \\
\hline 14 & photographs of them in the house. \\
\hline 15 & When he had been younger, Harry had dreamed and dreamed of some \\
\hline 16 & unknown relation coming to take him away, but it had never happened \\
\hline 17 & the Dursleys were his only family. Yet sometimes he thought (or maybe \\
\hline 18 & hoped) that strangers in the street seemed to know him. Very strange \\
\hline 19 & strangers they were, too. A tiny man in a violet top hat had bowed to him \\
\hline 20 & once while out shopping with Aunt Petunia and Dudley. After asking Harry \\
\hline 21 & furiously if he knew the man, Aunt Petunia had rushed them out of the shop \\
\hline 22 & without buying anything. A wild-looking old woman dressed all in green \\
\hline 23 & had waved merrily at him once on a bus. A bald man in a very long purple \\
\hline 24 & coat had actually shaken his hand in the street the other day and then walked \\
\hline 25 & away without a word. The weirdest thing about all these people was the way \\
\hline 26 & they seemed to vanish the second Harry tried to get a closer look. \\
\hline 27 & At school, Harry had no one. Everybody knew that Dudley's gang hated that \\
\hline 28 & odd Harry Potter in his baggy old clothes and broken glasses, and nobody \\
\hline 29 & liked to disagree with Dudley's gang." (ROWLING, 1997, p. 27) \\
\hline
\end{tabular}

This is the last excerpt that I will discuss in this section and it closes chapter 2, revealing to the readers Harry's feelings and thoughts.

The author begins setting the scene in the first paragraph (lines 1 to 4), which mixes material, relational and mental processes. She tells what Harry is doing (material clause, "lie", line 1), where he is ("in his cupboard", circumstantial element of place, line 1) and when ("much later", circumstantial element of time 
related to the last scene). Right after this, there is a mental process ("wish", line 1) followed by the relational process ("have", line 1), conveying that Harry does not have a watch and therefore doesn't "know" (mental process, line 2) the time. Then, Rowling uses a relational process ("be", line 2) followed by an attribute ("sure", line 2) to indicate that he needed to know if his relatives were sleeping, to "risk sneaking" (material processes, line 4) to get some food, conveying that he is hungry.

Lines 5 to 12 bring a material process ("live", line 5) mixed with relational processes ("be", lines 6 and 7) and mental processes ("remember", lines 6, 7 and 12; "strain [the memory]", line 8; "come up with", line 9; suppose, line 10; and imagine, line 11). The relational process "be" in line 5 is followed by two circumstantial elements one of manner ("with the Dursleys", line 5) and other of duration ("for almost ten years"). It is interesting that the author chose to repeat the duration adding the epithet "miserable" (line 5), indicating how bad things were for Harry. Right after this, there is a circumstantial element ("as long as", lines 5 and 6), followed by a mental process ("remember", line 5) and another circumstantial element ("ever since", line 6) and a relational process. All these processes and circumstances seem to be used to reveal to the readers Harry's memories: he does not remember anything before living with the Dursley, except for one vision, which the author qualifies with the epithet "strange" (line 9). This vision is then described with three other epithets ("blinding" and "green" [light], line 9; and "burning" [pain], line 10) and a circumstantial element of place ("on his forehead", line 10). The last mental process in this paragraph ("remember", line 12) followed by the circumstantial element "at all" lets the reader know that Harry really has no recollection of his parents. Then, there is a relational process ("be", line 13) followed by an attribute "forbidden" (line 13) and a verbal process (ask), informing once more that Harry is not allowed to ask questions. The paragraph ends with an existential process (line 14), which implies that Harry had never seen a picture of his parents.

The following paragraph begins with a relational process ("be", line 15) and an attribute, "younger" (line 15), followed by a mental process (“dream", line 15) which is repeated to indicate that he really wished he had other relatives that could save him from the Dursleys. Right after this, the author uses an existential process (line 16) to indicate that this never happened. Then, she uses two mental processes ("think" and "hope", lines 17 and 18) to indicate a feeling, a sensation that he had 
that strangers seem to know him, but he failed to confirm this when "tried to get a closer look" (material process, line 26).

This excerpt ends with a rather sad paragraph. The author uses a relational process ("have", line 27) to inform the readers that Harry does not have friends at school and all because of his cruel relatives. The author uses a set of epithets to show the readers how Harry is perceived by his classmates: "odd" (line 28), with "baggy, old clothes and broken glasses" (line 28).

\subsection{Excerpts from The Cuckoo's Calling}

\section{- CS-1 - Strike's introduction}

1 The name on the paper beside the outside buzzer was engraved on the glass

2 panel: C. B. Strike, and, underneath it, the words Private Detective."

3 (GALBRAITH, 2013, p. 17)

This is the first time Cormoran Strike is mentioned in the book. Even though he does not figure as an active participant, the author introduces the protagonist informing the reader his name and what he does for a living (line 2). This way, when she finally presents the protagonist as an active participant, the readers have already built some expectations.

\section{- CS-2 - Strike's first action}

\begin{tabular}{|ll|}
\hline 1 & Strike absorbed the impact, heard the high-pitched scream and reacted \\
2 & instinctively: throwing out a long arm, he seized a fistful of cloth and flesh; \\
3 & a second shriek of pain echoed around the stone walls and then, with a \\
4 & wrench and a tussle, he had succeeded in dragging the girl back on to firm \\
5 & ground. Her shrieks were still echoing off the walls, and he realized that he \\
6 & himself had bellowed. 'Jesus Christ!'" (GALBRAITH, 2013, p. 18)
\end{tabular}

This is the very first paragraph of the second chapter and I really loved this excerpt because it gave me so many surprising elements to analyze and it is full of hints and clues related to the protagonist.

I think it is fascinating that J. K. Rowling chose to use three behavioral processes in row - "absorb", "hear" and "react" (line 1) - to introduce a character, followed by a circumstantial element of manner "instinctively" (line 2), enhancing even more that his actions were a psychological and a physiological response to things happening in front of him. In my opinion, this is a hint that this character is 
being constructed by means of the author's lexical choices as a man of action, who reacts to things around him almost without thinking.

The second hint we see in this excerpt regards Strikes' physical appearance. In line 2 , there is a material process ("throw out") followed by a nominal group "long arm", indicating that Strike is probably big. Both material processes in line 2 reveals that our hero is rough, he does not extend an arm to save the girl in danger, but rather "throws" it and "seize" not only her clothes but her flesh as well. In order to avoid her fall, he hurts her. Here, I feel that the author, through her lexical choices, is probably trying to break the readers' expectations that our detective will be someone charming, dignified and stylish for whom everything works perfectly as planned. This is confirmed by the circumstantial element of manner in lines 3 and 4 ("with a wrench and a tussle") and by the material process "drag" in line 4 , which, in my point of view, characterize our hero as someone rough and ungracious. Notice that the author chose not to use the word "save" to describe Strikes' actions to avoid Robin's fall; after all, he dragged her to firm ground (line 4). All the material processes (lines 2 and 3 ) and the circumstance (lines 3 and 4) conveys an image to the reader of a character who does not plan his actions but is ready for action.

When we analyze the only verbal process of this excerpt, "bellow" (line 6), combined with the mental one, "realize" (line 5), this impression is once again reinforced: Strikes only realized he had bellowed after he heard his own voice.

As I commented above, this short excerpt gave us many hints and clues about our hero regarding both his physical appearance and his personality: he is possibly big, he is rough and unpolished, he acts by instincts.

Let's see one more excerpt from this same scene that gives more information about Strike.

\section{- CS-3 - After the action}

\begin{tabular}{|ll|}
\hline 1 & Judging by the lopsided way she was hunched, with one hand buried deep \\
2 & under the lapel of her coat, Strike deduced that he had saved her by \\
3 & grabbing a substantial part of her left breast. A thick, wavy curtain of bright \\
4 & blonde hair hid most of the girl's blushing face, but Strike could see tears of \\
5 & pain leaking out of one uncovered eye. \\
6 & 'Fuck-sorry!' His loud voice reverberated around the stairwell. "I didn't \\
7 & see you-didn't expect anyone to be there..." (GALBRAITH, 2013, p. 18)
\end{tabular}


The mental processes ("deduce", line 2; "see", line 4; and "expect", line 7) suggests that, after all the action, it seems that Strike stopped to evaluate the situation. This time, the author chose the word "save" (line 2) to describe his actions because it is how Strike interpreted his actions; in other words, he is the senser in this clause and it is his consciousness that is being realized here. However, the idea of roughness of the character is implied again by the material processes in lines 3 ("grab") and 6 ("reverberate") and the description of the girl's posture and demeanor (not analyzed here, but considered in the interpretation). Analyzing all the hints and clues I found in this excerpt, I feel that my interpretation that he is brute and rough is confirmed by the way he apologizes in a loud voice that "reverberates" (line 6), using a curse word (line 6), and almost putting the blame on her when he said that he "didn't expect anyone to be there" (line 7). He didn't try to be kind or to comfort her.

The excerpt CS-4, not discussed in this chapter but included in the Appendix and marked according to Table 5, gives yet more hints about his roughness. For instance, he does not open the door, "he pushes it open" (line 2) and them "slams" it (line 5).

\section{- CS-5 - Strike's physical appearance through Robin's eyes}

\begin{tabular}{|ll|}
\hline 1 & Her accidental assailant was massive, his height, his general hairiness, \\
2 & coupled with a gently expanding belly, suggested a grizzly bear. One of his \\
3 & eyes was puffy and bruised, the skin just below the eyebrow cut. Congealing \\
4 & blood sat in raised white-edged nail tracks on his left cheek and the right \\
5 & side of his thick neck, revealed by the crumpled open collar of his shirt. \\
6 & (GALBRAITH, 2013, p. 19)
\end{tabular}

This first description of Strike's physical appearance is given through Robin's eyes. As I have commented in the previous excerpts, the author left several lexicogrammatical hints that Strike might be big, and this is confirmed here in the first description of the detective through a relational process ("be", line 1) and the attribute "massive".

It is interesting to notice in line 1 that Rowling uses noun groups ("his height" and "his general hairiness") to inform the reader that Strike is tall and hairy. This information is followed by a noun group formed by a circumstance of degree ("gently", line 2), an epithet ("expanding", line2) and a noun ("belly", line 2) to indicate that he is slightly overweight. All these noun groups function as the actor 
for the material process ("suggest", line 2) and the goal is another noun group "grizzly bear", which reinforces his size.

In this excerpt, we find lots of attributes and epithets, but only two relational processes ("be", lines 1 and 3) and three material ones ("suggest", line 2; "sit", line 4; "reveal", line 5). I believe that here, the attributes tells us more than the processes. The attributes/epithets in lines 1, 2 and 3 (massive, expanding and thick) describe Strike's physical appearance in general, but all the others describe his appearance at that specific moment, indicating that he might have had some kind of fight.

\section{- CS-7 - More information about Strike's situation and appearance}

\begin{tabular}{|ll|}
\hline 1 & "Strike made a rapid mental calculation. A week at the agency's exorbitant \\
2 & rate would drive his overdraft yet further into the region of irreparable; \\
3 & might even be the final straw his main creditor kept implying he was \\
4 & waiting for. \\
5 & "Scuse a moment'. \\
6 & He left the room via the glass door, and turned immediately right, into a \\
7 & tiny dank toilet. Here he bolted the door, and stared into the cracked, spotted \\
8 & mirror over the sink. \\
9 & The reflection staring back at him was not handsome. Strike had the high, \\
10 & bulging forehead, broad nose and thick brows of a young Beethoven who \\
11 & had taken to boxing, an impression only heightened by the swelling and \\
12 & blackening eye. His thick curly hair, springy as carpet, had ensured that his \\
13 & many youthful nicknames had included "Pubehead," He looked older than \\
14 & his thirty-five years." (GALBRAITH, 2013, p. 20)
\end{tabular}

This excerpt begins with a mental clause realized through the process "make (a mental calculation)" (line 1) to introduce the idea that Strike is broke, his finances are qualified with the attribute "irreparable" (line 2). For me, the author is building this character brick by brick, giving a series of lexical hints and clues to help the readers to form their image of the detective, who is big, seems to be rough and impolite, appears to act first and think later, and has financial problems.

Then, in line 5, the author uses the detective' voice to break the narrative of what is happening, without using a verbal process. Reading further, we see that the author uses three material processes ("leave" and "turn", line 6; and "bolt", line 7) and a set of circumstantial elements ("via the glass door" and "immediately", line 6) to describe how the protagonist left the room. In my opinion, she used the circumstantial elements to further increase the idea of movement given by the material processes. Right after this, Rowling chose a mental process "stare" (line 7) to indicate that Strike finally stopped doing things and is going to think. 
For me it is fascinating that the author put Strike staring at a mirror and sharing what he sees with the reader. So, from lines 9 to 14 , the author gives us a description of the detective. This excerpt presents lots of attributes and epithets, but fewer processes, like we saw in CS-5. I believe that Rowling chose to do this again because once again the attributes give more information to the readers than the processes since this is a description of the protagonist's physical appearance. However, it is interesting to notice that from lines 9 to 14 , there are only three relational processes ("be" and "have", in line 9; "look", in line 13), one mental ("stare", line 9) and two material ("take", line 11; and "ensure", line 12) and 13 attributes in the same lines.

The first attribute she uses is "not handsome" (line 4). She does not affirm that Strike is ugly; she just informs that the reflection he sees is not handsome, and then she begins to describe his appearance. The epithets in line 9 ("high") and 10 ("bulging", "broad" and "thick") construct the idea of substantiality, highlighting the idea that he is huge and "massive", as we saw in CS-5, line 1. In lines 11, 13 and 14, Rowling indicates that Strike is not what he looks like. In line 11, she uses a material process ("take") to imply that he looks like a boxer (which he is not); and in line 13, she uses a relational process ("look") to inform two things to the readers: his age - he is 35 years old - and that he seems older.

There is no information about the color of Strike's eyes but plenty about his hair, which is "thick" (line 12) - again an attribute that elicit the idea of something sizable - and "curly" (line 12). Then she uses an attribute followed by circumstantial element of manner ("springy as a carpet", line 12) to bring to the readers' minds a very vivid image, which she makes stronger by telling one of the nicknames he had when he was teenager: "Pubehead". In these lines about his hair, the author leaves no open space for interpretation. His hair is exactly as she described.

After reading this description, for me, as a reader and researcher, he seems to be ugly but I believe that when Rowling used the attribute "not handsome" in line 9, she wanted to leave this open to the readers' own interpretation. 


\section{- CS-10 - Strike's current situation and state of mind}

\begin{tabular}{|ll|}
\hline 1 & He strode into the inner office, closed the door carefully behind him and \\
2 & then stood quite still, gazing at the kitbag under the bare desk. It contained \\
3 & everything he owned, for he donbted that he would ever see again the nine \\
4 & tenths of his possessions he had left at Charlotte's. They would probably be \\
5 & gone by lunchtime; set on fire, dumped in the street, slashed and crushed, \\
6 & doused in bleach. The drill hammered relentlessly in the street below. \\
7 & And now the impossibility of paving off his mountainous debts, the \\
8 & appalling consequences that would attend the imminent failure of this \\
9 & business, the looming, unknown but inevitably horrible sequel to his leaving \\
10 & Charlotte; in Strike's exhaustion, the misery of it all seemed to rear up in \\
11 & front of him in a kind of kaleidoscope of horror. \\
12 & Hardly aware that he had moved, he found himself back in the chair in \\
13 & which he had spent the latter part of the night. From the other side of the \\
14 & insubstantial partition wall came muffled sounds of movement. The \\
15 & Temporary Solution was no doubt starting up the computer, and would \\
16 & shortly discover that he had not received a single work-related email in \\
17 & three weeks. Then, at his own request, she would start opening all his final \\
18 & demands. Exhausted, sore and hungry, Strike slid face down on to the desk \\
19 & again, muffling his eyes and ears in his encircling arms, so that he did not \\
20 & have to listen while his humiliation was laid bare next door by a stranger." \\
21 & (GALBRAITH, 2013, pp. 22,23 )
\end{tabular}

This is the last excerpt of The Cuckoo's Calling that I will analyze and it closes the second chapter of the book, revealing to the reader Strike's state of mind regarding his current situation.

The author opens the first paragraph of this excerpt with three material processes ("stride" and "close, line 1; and "stand", line 2), describing how Strike left Robin and came into his room. Then, she introduced a mental process ("gaze", line 2) followed by a circumstantial element of place ("at the kitbag under the bare desk", line 2) to convey that he is going to think. Right after this, we have one more material process ("own", line 3), followed by two other mental processes ("doubt" and "see", line 2). The author uses these processes to indicate that Strike does not have many things and that he won't recover the possessions that are not with him at that moment.

In excerpt CS-8 - not analyzed in this chapter, but transcribed in the Appendix and marked according Table 5-, Rowling described what happened to Strike before he saved Robin: A big fight with his girlfriend, leaving some clues that he might be in an abusive relationship (see CS-8, lines 5 to 8 and 12 to 13). She brings this idea back in lines 4 to 6 of excerpt CS-10 (not market), when Strike thinks about what Charlotte might have done to his clothes and possessions. 
Lines 7 to 11 reaffirms what we have seen in CS-7: Strike has some serious financial problems. In this paragraph, there are only three material processes ("pay", line 7; "attend", line 8; and "leave, line 9), but six epithets, which, with the circumstantial elements, inform the readers the gravity of his situations. In line 7 , the epithet used to qualify his debts is "mountainous", which, of course, implies a very high amount of money but also brings to mind the image of an obstacle that would be very difficult to overcome. Then, Rowling uses the epithets "appalling", "imminent" "looming", "unknown" and "horrible" (lines 8 and 9) and the circumstantial element of manner (inevitably) to qualify his situation. All these choices seem to convey that he does not see how to solve his current problems and to indicate that things are getting worse and worse and he can't do anything to change it. First, he left Charlotte in a very violent way (see CS-8 in the Appendix) and now he is facing an inevitable bankruptcy. It is interesting to see that instead of using more epithets and attributes to further qualify the detective and his situation, the author chose to use a series of noun groups, which are not the focus of this paper, but are relevant to characterize our detective: Strike is exhausted and miserable (line 10), and horrible (line 11) things keep happening to him.

Line 12 opens with a circumstantial element of manner ("hardly") followed by an attribute ("aware") and three material processes ("move", "find" and "spend"), which seem to reinforce the idea that Strike is a person who acts by instinct and without thinking. He was not conscious of his movements, he just moved and when he realized, he was sitting in the same chair in which he had slept in the previous night. In line 16, the material process "receive" followed by the epithet "work-related" and the circumstantial element of extent "in three weeks" seems to reinforce even more his horrible work situation presented in lines 7 to 9 .

The chapter ends with a long sentence (lines 18 to 20) that begins with three attributes in a row "exhausted, sore and hungry" (line 18). These attributes describe in a quite simple and direct way how Strike is feeling at that exact moment. I believe that the author here does not want to leave space for interpretation she wants the reader to know exactly how the detective is feeling. Then she uses two material processes ("slide", line 18; and "muffle", line 19) and a circumstantial element of place ("in his encircling arms", line 19) that seem to imply how destroyed and exhausted he is and that he wants to block the sounds and the view around him. In line 20 , there is a combination of a relational process ("have"), a mental process 
("listen") and a material one ("lay") which indicates that Strike wants to avoid the sounds that come from next door that reveals his humiliation.

As we can see, in this excerpt, the detective is financially ruined, exhausted, sore, humiliated, and does not know how he is going to overcome his dire situation. 


\section{Discussion based on lexicogrammar analysis}

Observing the analysis of the chosen excerpts in the previous chapter, I feel that J. K. Rowling has a very rich narrative and that she masterfully uses different process types to build her characters and not only relational processes followed by attributes as one might expect (HALLIDAY; MATHIESSEN, 2004, p. 174).

Even though this is a qualitative research, I believe that the quantitative data in the tables below will help me to better understand, compare and interpret the strategies used by the author to build her protagonists.

According to Halliday and Mathiessen (2004) "the setting and orientation of a narrative is often dominated by 'existential' and 'relational' clauses, but the main event line is construed predominantly by 'material' clauses" (HALLIDAY; MATHIESSEN, 2004, p. 174). Tables 6 and 7 below shows us how Rowling mixes the types of processes to give flavor and style to the narrative instead of only using relational clauses and attributes to build her protagonists.

I noticed that her word choices are full of intent and I will try to compare the choices she made for each book and discuss this further in this chapter according to the categories analyzed.

Table 6. Summary of the processes*, circumstances and attributes found in the excerpts from Harry Potter and the Philosopher Stone

\begin{tabular}{|l|l|c|}
\hline Type & Example & $\begin{array}{l}\text { Number of } \\
\text { occurrences }\end{array}$ \\
\hline Material process & $\begin{array}{l}\text { to roll, to try, to get out, to start, to find; to pull; to put; } \\
\text { to go; to wear; to get; to turn; to put; to begin; to wolf; } \\
\text { to sit; to make; to come back; to spend; etc. }\end{array}$ & 63 \\
\hline Mental process & $\begin{array}{l}\text { to remember; to have (a dream); to forget; to like; to } \\
\text { see; to hate; to feel; to remind; to look (at); to } \\
\text { understand; to believe; to imagine; to explain; etc. }\end{array}$ & 57 \\
\hline Relational process & to be; to have; to look (like) & 46 \\
\hline Verbal process & to say; to ask; to shout; to talk about; to murmur & 14 \\
\hline Behavioral & to hear; to groan; to sleep; to gasp; & 7 \\
\hline Existential & to be; to happen; & 6 \\
\hline Attributes & $\begin{array}{l}\text { asleep; good (dream); funny (feeling); used; dressed; } \\
\text { small; skinny; old (clothes ); (not) big; etc. }\end{array}$ & 55 \\
\hline $\begin{array}{l}\text { Circumstantial } \\
\text { elements }\end{array}$ & $\begin{array}{l}\text { fast; curiously; like a bolt of lightning; with a start; } \\
\text { slowly; very; really; in the dark cupboard; simply; } \\
\text { often; as fast as possible; every year; honestly; caught } \\
\text { by surprise; hard; almost; sometimes; maybe etc. }\end{array}$ & 98 \\
\hline
\end{tabular}

*Some of the processes here could be classified differently. However, I am classifying them taking into account the context in which they were used, which in in accordance with a SFL perspective. 
Table 7. Summary of the processes*, circumstances and attributes found in the excerpts from The Cuckoo's Calling

\begin{tabular}{|c|c|c|}
\hline Type & Example & $\begin{array}{l}\text { Number of } \\
\text { occurrences }\end{array}$ \\
\hline Material process & $\begin{array}{l}\text { to throw out; to seize; to succeed; to drag; to save; to } \\
\text { grab; to push open; to usher; to slam; to leave; to turn; } \\
\text { to bolt; to ensure; to empty; to ram; etc. }\end{array}$ & 55 \\
\hline Mental process & $\begin{array}{l}\text { to realize; to deduce; to see; to expect; to stare; to } \\
\text { know; to remember; to intend; to make (a mental } \\
\text { calculation); to stare; to look back; etc. }\end{array}$ & 2 \\
\hline Relational process & to be; to have; to look (like); to suggest; etc. & 8 \\
\hline Verbal process & to bellow; to ask; to say; to speak & 4 \\
\hline Behavioral & $\begin{array}{l}\text { to absorb; to hear; to react; to sleep; to take (a deep } \\
\text { breath) }\end{array}$ & 5 \\
\hline Existential & to be; & 2 \\
\hline Attributes & $\begin{array}{l}\text { loud (voice); massive; expending (belly); puffy and } \\
\text { bruised (eyes); cut (eyebrow); battered (face); rapid, } \\
\text { mental (calculation); not handsome; high, bulging } \\
\text { (forehead); broad (nose); thick (brows); etc. }\end{array}$ & 43 \\
\hline $\begin{array}{l}\text { Circumstantial } \\
\text { elements }\end{array}$ & $\begin{array}{l}\text { instinctively; gently; forever; immediately; } \\
\text { completely; with a gasp and a grunt; pleasantly; with } \\
\text { disgust; carefully; quite still; hardly aware; etc. }\end{array}$ & 59 \\
\hline
\end{tabular}

*Some of the processes here could be classified differently. However, I am classifying them taking into account the context in which they were used, which in in accordance with a SFL perspective.

The material processes constitutes "clauses of doing and happening" (HALLIDAY; MATHIESSEN, 2004, p. 179). Comparing both books, we can see that Cormoran Strike and Harry Potter do more or less the same number of things.

However, analyzing her word choices, I feel that the material processes related to Harry Potter in the chosen excerpts indicate a daily routine of waking up, dressing, preparing the breakfast, eating, sitting etc. It seems that she uses these descriptions of his routine to show the readers how hateful the Dursleys are and how impotent Harry is to change things. He "tries" to change things but is not successful. It is interesting to notice that in the beginning of the story, the author tells the readers that strange things happen to him but he believes that he doesn't make them happen (HP-12 and HP-13). The first time Harry does something different from his routine is in excerpt HP-16, when "he moved in front of the tank", starts to observe the snake, "winks" at it and reads the signs.

Cormoran Strike, on the other hand, is depicted from the very beginning as a man who is always moving. Actually, the first time Strike appears in the book as an active participant, he is taking action (CS-2, lines 2 and 4), whereas HP is asleep in 
the first three times he appears (HP-1, line 2; HP-2, lines 1 and 2; HP-3, line 2). Different from Harry, Strike is the one usually doing things and not having things done to him or for him. He saves, he grabs and seizes, he pulls and pushes, he slams doors, he plunges and strides. Rowling's choices here are quite colorful and full of movement. In my opinion, all these material processes convey an air of someone rough, strong, big and not elegant; for instance, Strike does not open the door, but pushes it open.

Comparing the use of material processes in the chosen chapters, I believe that Rowling uses them for different purposes. In Harry Potter and the Philosopher's Stone, it seems that she wants to convey the image of a young boy who is abused by his relatives, who is helpless to do something about it and must follow the rules; whereas in The Cuckoo's Calling, she uses this type of process to describe someone strong, big and active.

Mental processes are processes of sensing and feeling and are divided into four subtypes: perceptive, cognitive, desiderative, emotive. When we look at Tables 6 and 7 above, we can see that Rowling uses a lot more mental processes for Harry Potter than for Cormoran Strike. I decided to organize the mental processes found in the excerpts in their subtypes (see Table 8 below) to make it easier to analyze how this type of process helps in the construction of the characters' personas.

Table 8. Mental processes* found in the excerpts from Harry Potter and the Philosopher's Stone and The Cuckoo's Calling divided into subtypes

\begin{tabular}{|c|c|c|}
\hline Subtype & Harry Potter & Cormoran Strike \\
\hline perceptive & $\begin{array}{ll}\text { - } & \text { could see (HP-8) } \\
\text { - } & \text { "made him look" (HP-9) } \\
\text { - } & \text { "to wad to look" (HP-9) } \\
\text { - } & \text { "looked" (HP-10) } \\
\text { - } & \text { "stared" (HP-16) } \\
\text { - } & \text { "looked" (HP-16) } \\
\text { - } & \text { "to see" (HP-16) } \\
\text { - } & \text { "looked back" (HP-16) } \\
\text { - } & \text { "peered" (HP-16) }\end{array}$ & 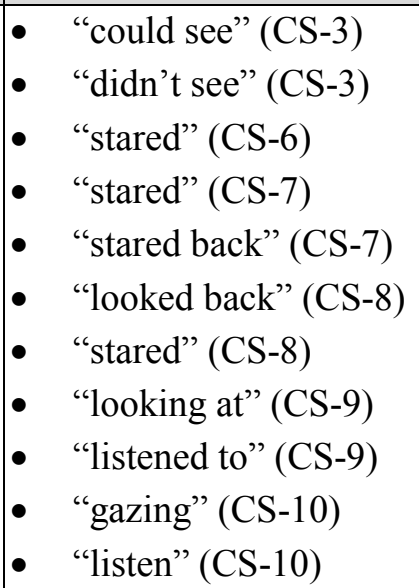 \\
\hline cognitive & $\begin{array}{ll}\text { - } & \text { "not knowing" (HP-2) } \\
\text { - } & \text { "remember" (HP-3) } \\
\text { - } & \text { "had (a good dream) (HP-3) } \\
\text { - } & \text { "had forgotten" (HP-4) }\end{array}$ & $\begin{array}{l}\text { - } \quad \text { "realized" (CS-2) } \\
\text { - } \quad \text { "deduced" (CS-3) } \\
\text { - "didn't expect" (CS-3) } \\
\text { - "knew" (CS-6) }\end{array}$ \\
\hline
\end{tabular}




\begin{tabular}{|c|c|c|}
\hline & 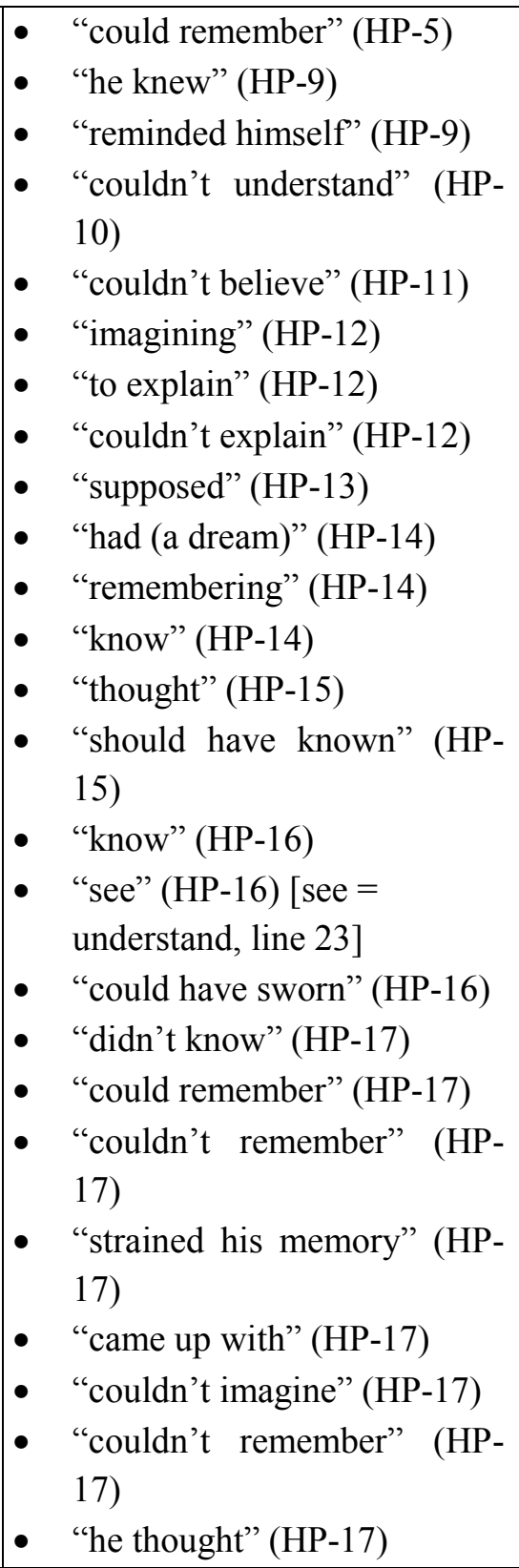 & $\begin{array}{l}\text { - "remembered" (CS-6) } \\
\text { - "intended" (CS-6) } \\
\text { - "made a mental calculation" } \\
\text { (CS-7) } \\
\text { - "(thoughts) flickered thorough } \\
\text { (his mind)" (CS-8) } \\
\text { - "knew" (CS-9) } \\
\text { - "doubted" (CS-10) }\end{array}$ \\
\hline desiderative & 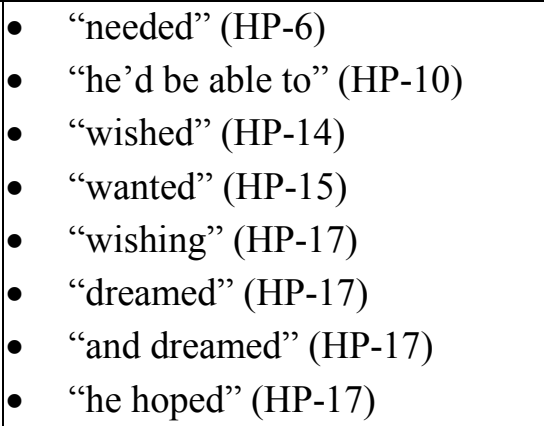 & \\
\hline emotive & $\begin{array}{ll}\text { - } & \text { "liked about his appearance" } \\
& \text { (HP-5) } \\
\text { - } & \text { hated it there (HP-9) } \\
\text { - } & \text { ought to feel sorry (HP-9) }\end{array}$ & \\
\hline
\end{tabular}

*Some of the processes here could be classified differently. However, I am classifying them taking into account the context in which they were used, which in in accordance with a SFL perspective. 
In terms of perceptive mental processes, Harry and Cormoran Strike have more or less the same perceptions. However, when we analyze the cognitive subtype, it is possible to notice that the author chose the words to fit the character's age. Harry is almost 11 years old, so he thinks, remembers, imagines, believes, knows and thinks, whereas Strike, who is 35 years old, in addition to knowing, remembering and thinking, also deduces, expects, makes mental calculation, doubts.

In the excerpts analyzed, I did not find any emotive or desiderative mental process in The Cuckoo's Calling. Harry, on the other hand, is someone who dreams, hopes, wishes and wants. J. K. Rowling also informs the readers about his feelings. I think that the author's choice of mental processes for Harry Potter and the Philosopher's Stone reinforces the idea of a young helpless boy and brings another element to his description, a curious, hopeful and sensitive character who tries to understand the miserable life he has. In The Cuckoo's Calling, the mental processes are used to show an experienced and intelligent man, who seems to not expect anything and that does not show his feelings. When comparing the material processes with the mental ones in this book, the reader can conclude that Strike is a man who acts first and thinks later, reinforcing the idea of man of action.

Relational processes are used "to characterize and to identify" (HALLIDAY; MATHIESSEN, 2004, p. 210) and establish a relation between two entities. Therefore, we could expect to find a close relation between its use and the use of attributes.

If we look at the data regarding Harry Potter and the Philosopher's Stone in Table 6, this expectation seems to be fulfilled since the number of relational processes (46) and attributes (55) are close.

However, if we look at the data related to The Cuckoo's Calling in Table 7, we see a completely different relation: there are only 8 relational processes and 43 attributes. Looking at the excerpts listed in in the Appendix, it is possible to notice that in The Cuckoo's Calling, the author used other strategies when it came to attributes and epithets instead of only attributive relational clauses, using nominal groups formed by modifiers, epithets and nouns. Let's consider, for instance, lines 9 and 10 of excerpt CS-7: 


\begin{tabular}{|c|c|c|c|c|c|c|c|c|c|c|c|c|c|c|}
\hline Strike & had & the & bight, & bulging & forehead, & broad & \begin{tabular}{|l|} 
note \\
\end{tabular} & and & \begin{tabular}{|l|l} 
thick \\
\end{tabular} & brows & of & 8 & young & Beethoven \\
\hline Actor & rel. pros: & Determ: & epithet! & epithet2 & thing & epithet & thing & & equithet & ithing & prep & & epithet & thing \\
\hline participant & & & & & & & nomi & 1 gron & & & & & & \\
\hline
\end{tabular}

What we see here is one relational process presenting a "possessive relation" (HALLIDAY; MATHIESSEN, 2004, p. 211), followed by a row of nominal groups formed by epithet and nouns.

The author uses another strategy in lines 12 and 13 of the same excerpt, beginning the sentence with a nominal group formed by epithets and noun functioning as the participant of the material process ("ensure"), followed by circumstantial element of comparison, as follows:

\begin{tabular}{|l|l|l|l|l|l|l|l|}
\hline His & thick & curly & hair, & springy & as & carpet, & had ensured... \\
\hline determiner & epithet $_{1}$ & epithet $_{2}$ & thing & attribute & prep. & thing & material process \\
\hline \multicolumn{4}{|c|}{ participant } & \multicolumn{3}{c}{ circ. elem. of comp. } \\
\cline { 2 - 4 }
\end{tabular}

Another strategy Rowling used with attributes was to completely omit the relational process "be", as we can see in lines 17 and 18 of CS-8: "...his face and head pleasantly numb and tingling..."

Verbal processes make "it possible to set up dialogic passages" (HALLIDAY; MATHIESSEN, 2004, p. 252) and gives voice to the characters in a narrative. We can see in Tables 6 and 7, that, in the beginning of the book, Harry Potter verbalizes a lot more than Strike, and that it is worth analyzing a little bit further.

I believe that every time Rowling gives voice to Harry in chapter two, this is somewhat related with the way Harry is treated by his relatives. Let' consider HP3, line 1, "The room held no sign at all that another boy lived in the house, too.", and in HP-10, lines 1 to 3, "The Dursleys often spoke about Harry like this, as though he wasn't there - or rather, as though he was something very nasty that couldn't understand them, like a slug.". As we can see, Harry is treated as if he does not exist. For me, each time he says, shouts or asks something, it seems to convey that he is making a statement saying that he does exist and that he wants to be seen and heard.

Strike, on the other hand, seems to be someone who acts first and thinks later; someone rough who does not feel the need to be kind, or to explain himself. The first time the author gives voice to Strike is in excerpt CS-2, lines 5 and 6: “... and 
he realized that he himself had bellowed, 'Jesus Christ!'”. I believe that this verbal process (bellows) conveys a lot more than just giving a voice to the protagonists. Indeed, here he does not have anything to say. It is an exclamation, which, in my opinion, reinforces the idea shown in CS-2 that Strikes is a man who reacts to things that are happening around him. Another thing worth mentioning is that the author gives voice to Strike in three different moments throughout chapter 2 without using a verbal process. In CS-3, line 6, he uses a swear word and apologizes "in a loud voice" that "reverberates"; in CS-4, line 1, he invites Robin in, and in CS-7, line 5, he asks to be excused. Based solely in the excerpts listed and marked in the Appendix, it seems to me that Strike only speaks by reaction, when he has something relevant to say and when he wants or needs to know something. Of course, the use of verbal processes should be further investigated in the other chapters to better understand how Strike interacts verbally with other characters, which is not within the scope of this monograph.

Behavioral processes are related to "physical and psychological behavior" (HALLIDAY; MATHIESSEN, 2004, p. 248) and their boundaries are fuzzy because they can be really close to mental, verbal and material processes. For this analysis, I classified as behavioral the processes that occur in an almost unconscious way; in other words, almost as physical or psychological reactions. This classification, thus, is rather subjective and other researchers might disagree with my interpretation.

Comparing the data in Tables 6 and 7, we can see 7 behavioral processes related to Harry and 5 related to Strike. However, if we look closer to the processes realized by each one of them, we can recognize that the ones related to Harry Potter are closer to mental processes and the ones related to Strike are closer to material processes as shown in Table 9 below. If we consider the process "take" and the scope "a deep breath" (CS-8, line 2), it is possible to see that, even though "to breathe" is a physiological behavior that cannot be avoided, when a process "take" is used followed by an epithet "deep" and the noun "breath", there is some intention to this process. In this case, "take" can be classified as a behavioral process but, in my opinion, this intention makes it closer to a material process. 
Table 9. Behavioral processes found in the excerpts from Harry Potter and the Philosopher's Stone and The Cuckoo's Calling

\begin{tabular}{|c|c|}
\hline Harry Potter & Cormoran Strike \\
\hline $\begin{array}{l}\text { to sleep (HP-2, line 2; HP-4, } \\
\text { line 5) } \\
\text { - to wake (HP-3, line 6) } \\
\text { - to hear (HP-3, line 6) } \\
\text { - to grow (HP-6, line 6; HP-12, } \\
\text { line 14) } \\
\text { - } \text { gasp (HP-16, line 35) }\end{array}$ & 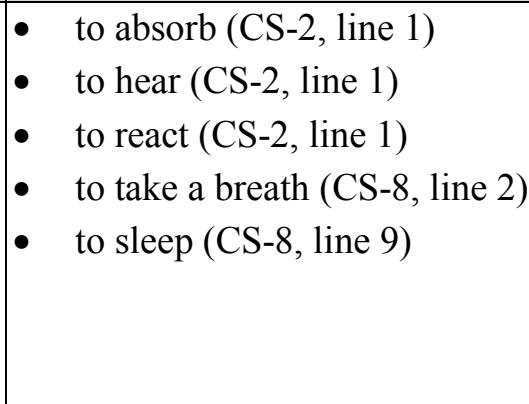 \\
\hline
\end{tabular}

Existential clauses "represent something that exists or happens" (HALLIDAY; MATHIESSEN, 2004, p. 256) and, in a narrative, can be used to in to introduce characters in the beginning of a story participants (HALLIDAY; MATHIESSEN, 2004, p. 257). Therefore, I was expecting to find more existential processes in the beginning of both books. However, I only found few existential clauses in the chosen excerpts of Harry Potter and the Philosopher's Stone and even fewer in The Cuckoo's Calling. In my opinion, J. K. Rowling used her creativity and talent to find different ways to introduce characters and scenes, mixing different processes and strategies to construe the story and the characters' personas. One good example of this can be seen in CS-1, when she informs the readers the name of the protagonist and what he does for a living, without using any process related to the protagonist.

To finish this chapter, I am going to consider on circumstances, which are not mandatory in the sentence but add information regarding place, time, manner, cause etc. and "serves as an expansion of something else" (HALLIDAY; and MATHIESSEN, 2004, p. 261). They are usually realized as prepositional phrases, like "Harry woke with a start" (HP-3, line 6) or an adverbial group, like "Hardly aware that he moved..." (CS-10, line 12).

If we look at tables 6 and 7 above, we see that J. K. uses lots of circumstantial elements during the narrative, since these elements are important to build the story, locating the scenes and actions in place and time, showing how a character is doing something, his purpose and so on. Table 10 shows some examples of circumstances used in both books, classified according to their type. 
Table 10. Examples of circumstantial elements found in the excerpts from Harry Potter and the Philosopher's Stone and The Cuckoo's Calling divided into subtypes

\begin{tabular}{|c|c|c|}
\hline Type & Harry Potter & Cormoran Strike \\
\hline $\begin{array}{l}\text { Extent } \\
\text { (distance, } \\
\text { duration, } \\
\text { frequency) }\end{array}$ & $\begin{array}{l}\text { - “...but Harry had } \underline{\text { always }} \\
\text { been small" (HP-5, lines } 3 \\
\text { and 4) }\end{array}$ & $\begin{array}{l}\text { - “...where he had slept for one } \\
\text { hour or two..." (CS-8, line 9) }\end{array}$ \\
\hline $\begin{array}{l}\text { Location } \\
\text { (place and time) }\end{array}$ & $\begin{array}{l}\text { - "Yet, Harry Potter was still } \\
\text { there" (HP-2, line 2) }\end{array}$ & $\begin{array}{l}\text { - "His loud voice reverberated } \\
\text { around the stairwell" (CS-3, } \\
\text { line 6) }\end{array}$ \\
\hline $\begin{array}{l}\text { Manner } \\
\text { (means, quality, } \\
\text { comparison, } \\
\text { degree) }\end{array}$ & $\begin{array}{l}\text { - “...they could see a } \\
\text { curiously shaped cut, like a } \\
\underline{\text { bolt of lighting” (HP-1, line }} \\
\text { 3) }\end{array}$ & 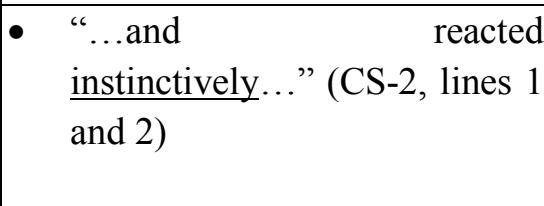 \\
\hline $\begin{array}{l}\text { Cause } \\
\text { (reason, } \\
\text { purpose, behalf) }\end{array}$ & $\begin{array}{l}\text { - "He had been given a week } \\
\text { in his cupboard for this..." } \\
\text { (HP-12, lines } 12 \text { and 13) }\end{array}$ & - \\
\hline $\begin{array}{l}\text { Contingency } \\
\text { (condition, } \\
\text { default, } \\
\text { concession) }\end{array}$ & - & - \\
\hline $\begin{array}{l}\text { Accompaniment } \\
\text { (comitative, } \\
\text { additive) }\end{array}$ & $\begin{array}{l}\text { - “...Harry was left behind } \\
\text { with Mrs. Figg...” (HP-9, } \\
\text { line 1) }\end{array}$ & $\begin{array}{l}\text { - Strike pushed opens the door } \\
\text { with his fingertips... (CS-4, } \\
\text { line 2) }\end{array}$ \\
\hline $\begin{array}{l}\text { Role } \\
\text { (guise, product) }\end{array}$ & $\begin{array}{l}\text { - "...to find his hair exactly } \\
\text { as it had been before..." }\end{array}$ & $\begin{array}{l}\text { - "His thick curly hair, springy } \\
\text { as carpet..." (CS-7, line 12) }\end{array}$ \\
\hline Matter & $\begin{array}{l}\text { - "The Dursleys often spoke } \\
\text { about Harry..." (HP-10, } \\
\text { line 1) }\end{array}$ & - \\
\hline $\begin{array}{l}\text { Angle } \\
\text { (source, } \\
\text { viewpoint) }\end{array}$ & - & - \\
\hline
\end{tabular}

In addition to give more information to the reader regarding place, time, manner etc., I have noticed that J. K. Rowling seems to use circumstances to leave some clues to the readers related to what comes next in the story. Let's consider, for example, the circumstantial element of duration "not for long" (HP-3, line 3). I believe that this is a clue that things are about to change. In HP-3, line 6 , there is another circumstance ("with a start") that, in my opinion, also conveys that things are about to change, as I discussed in pages 22, 23 and 47. 
Now, let's take an example from The Cuckoo's Calling. In lines 3 and 4 of CS-6 (not discussed in chapter 4, but transcribed and marked in the Appendix), there are three circumstances that, for me, are clues of what is going to happen: "Just like Robin", "forever" and "last twelve hours". The first one informs that Strike and Robin have something in common at that specific moment. However, for me it conveys a lot more, as if the author wanted to build parallels between these two character and show that even though their experiences are completely different (opposed as a matter of fact), they are related somehow. If we add the second and the third circumstances ("forever" and "last twelve hours"), one possible interpretation is that their fates were defined during those last hours, which includes their disastrous meeting!

It is important to inform here that Robin is going to help Strike solve the case he is assigned in this book, becoming his partner through the series that currently is in its third book. 


\section{Beyond Lexicogrammar}

"The aim of SFL is to find specific linguistic structures that make a text means what it means" (FUZER and CABRAL, 2014, p. 19), and this was exactly my objective for my monograph. So, after making all the markings in the excerpts in the Appendix, analyzing some of them in chapter 4 and discussing each category that I chose to analyze in chapter 5, I felt the need to go beyond lexicogrammar stratum. So I will briefly discuss here some strategies related to the semantic stratum that I believe the author used in both books to build her protagonist.

Even though these strategies were not defined in the scope of the research, I found them when was analyzing the lexicogrammar. I divided them into semantic groups, according to my interpretation. Of course, I only present and superficially comment on these groups since they are not the main objective of this monograph. However, I believe that this chapter might be full of suggestions pointing to several possible ways for other researches.

\subsection{Sleep}

The first three times Harry Potter appears as a participant in the story, he is asleep (HP-1, line 2; HP-2, line 2 and HP-3, line 2). One possible interpretation for this is that the author is trying to convey that Harry is not aware of his true self of being a wizard, and because of this he is presented sleeping (not conscious). It is also interesting how Harry wakes up in the beginning of chapter 2, "with a start". As I mentioned on page 23, I believe that this circumstantial element of manner can also be interpreted as a sign that the story is about to begin. Another recurring aspect is that when Harry sleeps, he has dreams about things that happened to him before he was left with his relatives, like the flying motorbike (HP-3, line 10; and HP-14, line 1) and "a blinding flash of green light and a burning pain in his forehead" (HP17, lines 9 and 10). J. K. also uses another element related to sleep for Harry Potter: Whenever he is worried about something he faces difficulties to sleep and had some sleepless nights of his own (HP-12, line 9)

Cormoran Strike, on the other hand, is presented in the beginning of the book as someone who is "battered" (CS-6, line 2), who only "slept for one or two hours in his desk chair" (CS-8, line 9), who is "exhausted" (CS-10, lines 10 and 18). All 
these choices seem to indicate that the detective has problems to sleep and desperately needs some rest.

I have read Harry Potter's whole series and I have noticed that this element and its variables (e.g., dreams, nightmares, sleeplessness, exhaustion) are brought several times. And this also happens throughout The Cuckoo's Calling, where we find things like "on verge of sleep" (GALBRAITH, p. 26), "Strike would have no alternative but to sleep rough" (GALBRAITH, p. 55), "and he could sleep in peace" (GALBRAITH, p. 58), etc. I believe that this choice by the author leaves room for further investigation so as to understand why this semantic aspect, that is, sleep seems to be an important narrative characteristic.

\subsection{Description of the characters}

One would expect to find a physical description of the protagonist right in the beginning of a story, with lots of attributes and relational clauses. However, when I was rereading the books to choose the excerpts, I found out that J. K. Rowling does not give a complete physical description of the characters at once. Instead, she leaves tips here and there about their appearance using, many times the view or the voice of other characters to give the readers information on the characters' physical appearance and character and not only the narrator's. For instance, we found out that Harry has black hair and a scar on the forehead through Dumbledore's and Professor McGonagall's view (HP-01, lines 2 and 3) and that Strike is massive, hairy and overweight (CS-5, lines 1 and 2) through Robin's eyes.

Another resource that she uses is the comparison to other characters to build strong descriptions and to induce more empathy in the reader. For instance, in chapter two the readers see how hateful the Dursley's are. So she uses this to give a brief description of Harry's physical appearance, comparing him to Duddley (HP5, lines 4 to 6). In The Cuckoo's Calling, Rowling also uses this strategy but not in chapters 1 and 2. I know I haven't analyzed here other chapters, but I would like to use the following excerpt as an example of how the author compares two characters to build their personas:

“The snowy smoothness of the stranger's shirt made Strike doubly conscious of the thousand or so creases in his own clothes. He stood up to give Bristow the full benefit of his six feet three inches, $\underline{\text { held }}$ 
out a hairy-backed hand and attempted to counter his visitor's sartorial superiority by projecting the air of a man too busy to worry about laundry." (GALBRAITH, 2013, p. 26)

Again, I think that this strategy deserves to be further investigated in another opportunity, analyzing this not only in relation to the protagonists but to other characters as well.

\subsection{Hair}

Reading the beginning of both books, I found it very peculiar how J. K. Rowling thoroughly describes the hair of the protagonists.

Indeed, the first information we have about Harry's appearance regards his hair, which is "jet-black" (HP-1, line 2) and this information is reinforced in HP-5, line 7. In HP-6, uncle Vernon barks that Harry should comb his hair (HP-6, line 2), implying that it was disheveled. Right after this, the author informs us that Harry's hair grows all over the place and that is no good having it cut (HP-6, lines 5 and 6). His hair is mentioned once again when his aunt tried to tame it by cutting almost all of it (HP-12, lines 7 and 8), only to see that it had grown back in the next day (HP12, lines 11 to 14$)$.

Strike's general hairiness is mentioned several times, for instance in CS-5, lines 1 and 2, and when he meets a client "held out a hairy-backed hand" (GALBRAITH, 2013, p. 26). The description of his hair is full of details, and the author uses many attributes and comparisons, not leaving space for an interpretation (CS-7, lines 12 and 13).

It seems to me that it is curious that the author gave so many details regarding the character's hair and the fact that she describes Harry's eyes simply as bright green (HP-5, line 7) and gives no information at all about the color of Strike's eyes.

\subsection{Scars}

As I mentioned in chapter 1, as a reader, one of the things that I noticed that these two novels had in common was that both protagonists are marked: Harry has a scar on the forehead and Strike does not have a leg. 
Harry's scar is described in the very first time he is mentioned in the book (HP-1, line 3), and right after this, Professor McGonagall asks if Dumbledore could remove it. His answer is quite interesting:

"Even if I could, I wouldn't. Scars can come in handy. I have one myself above my left knee that is a perfect map of the London Underground." (ROWLING, p. 1997, p. 17)

I believe that this is yet another hint that Harry's scar is somewhat special, which is reinforced later on:

"It happened very suddenly. The hook-nosed teacher looked past Quirrell's turban straight into Harry's eyes - and a sharp, hot pain shot across the scar on Harry's forehead." (ROWLING, p. 1997, p. 94)

Strike's condition, on the other hand, is not presented in the analyzed chapters. However, since this was one of the things that inspired me to begin this research, I decided that I should, at least, mention it.

The first time the author brings up this characteristic is on page 55, when Strike is thinking about the inadequacies of his life:

"...there was his recent weight gain; a full stone and a half, so that he not only felt fat and unfit, but was putting unnecessary additional strain on the prosthetic lower leg he was now resting on the brass bar beneath the table. Strike was developing the shadow of a limp purely because the additional load was causing some chafing. (GALBRAITH, 2013, p. 55)

Throughout the book, his prosthetic leg is mentioned several times, whenever he is preparing to sleep, when he has to go on a long walk or when he is tired and starts to limp.

I believe that if these distinctive markings on both characters were studied in details, the researcher might discover interesting information that may have helped the author to build their personas. 


\subsection{Orphanhood}

As I mentioned in chapter 1 of the monograph, both protagonists are motherless. Again, Harry is presented as an orphan in the very beginning, because this is a characteristic that defines him, but we only find out about the death of Strike's mother much later on the book.

However, when I was rereading the books I noticed something else. There are other orphan characters in both novels. In Harry Potter and the Philosopher Stone, Neville is an orphan who was raised by his grandmother. In The Cuckoo's Calling, in addition to Strike, Charlie, Lula and Bristow were all orphans.

I think that it would be interesting to investigate how J. K. Rowling uses this characteristic to develop each character, showing how each one of them dealt with the situation and became what they are.

\subsection{The characters' state of mind}

Even though these novels are for different target audiences and the problems each character is facing are quite different, the way the author presents their thoughts in the end of chapter 2 of both novels (HP-17 and CS-10) is very similar.

In HP-17, Harry is alone in his cupboard, waiting until his relatives are asleep to get some food. While he waits he starts thinking about his life, and those thoughts are pretty much a summary of his memories, his feelings and his wishes. It seems to me that the author is trying to convey an image of a young helpless boy who does not have any hope that things are going to change.

In CS-10, Strike is alone in his office and thinking about his life. However, his thoughts are not about his memories, feelings and wishes but about his current situation: he had just broken up with his girlfriend with whom he lived, he has a huge debt and about to lose everything he has. It seems to me that the author is trying to convey an image of helpless man, who feels like an absolute looser and who does not know how to solve the problems he has.

As we can see, J. K. Rowling closed chapter 2 of both novels depicting our heroes alone and thinking about their life, feeling helpless and unhappy, without knowing what to do. I believe that with this, she is revealing quite clearly their state of mind just before the twist of the story is about to be introduced. In Harry's case with the letter from Hogwarts, and for Cormoran Strike with a new client. 


\section{Final comments}

The first time I read Harry Potter and the Philosopher's Stone, J. K. Rowling's work fascinated me as a reader. When I saw the impact her work had in the editorial industry, it fascinated me as an editor. Now, that I have rounded up this monograph, I can say that I am fascinated as a researcher. Her stories open so many possibilities that it is difficult to stop looking for clues and new interpretations and new ways for research, as I commented on the previous chapter.

As I stated in chapter 1, when I read The Cuckoo's Calling, her second novel for an adult target audience, I noticed some similarities between the protagonist of that book - Cormoran Strike, the 35-year old detective - and Harry Potter, the eleven-year old wizard. So, I decided to look into it.

Exploring grammar from a systemic functional perspective helps to understand how meaning is created and expressed (HALLIDAY; and MATHIESSEN, 2004, p. 19). However, SFL is a very broad field offering a wide range of analytical possibilities and I had to narrow the scope of my research down. So, I decided to focus on the author's lexical choices to build the protagonists and what they might mean. Therefore, at this moment, the context of culture and the context of situation were not part of the scope of this work let alone the influence they might have played on my analysis.

Indeed, my goal was precisely to understand how J. K. Rowling construed the protagonists by analyzing her lexical choices regarding processes, circumstances and attributes. In Halliday's words "part of the 'flavour' of a particular text [...] lies in its mixture of process types" (HALLIDAY; and MATHIESSEN, 2004, p. 174). After discussing the lexicogrammatical features of the chosen excerpts in chapters 4 and 5, I was able to see how masterfully she combines the different types of linguistic elements to construe her characters, presenting the readers with a strong and rich narrative and leaving tips and clues, creating expectations in the readers that might be confirmed or not.

While analyzing the excerpt I really felt that each choice she made was carefully thought about. So, as a translator, I believe that one possible next step for me would be to discuss the Brazilian translators' choices for the excerpts analyzed here and see how these choices might have influenced or changed the meaning for Brazilian readers. 


\section{References}

BOWEN, Glenn A. "Document Analysis as a Qualitative Research Method". Qualitative Research Journal, Vol. 9 Iss 2 pp. 27 - 40, [s.1.]: Emerald Insight, 2009.

BBC. JK Rowling's Casual Vacancy wins mixed response. BBC News Entertainment \& Art, September, 27 2012. Available at: http://www.bbc.com/news/entertainment-arts-19740849. Accessed on September 72014.

BOLONIK, Kera. A List of Their Own. Salon.com, August 16 2014. Available at: http://www.salon.com/2000/08/16/bestseller/. Accessed on September 72014.

FLOOD, Alice. Potter Tops 400 Million Sales. The Bookseller, June 172008. Available at: http://www.thebookseller.com/news/potter-tops-400-millionsales.html. Accessed on September 202014.

FOX, How J. K. Rowling's Pseudonym Was Uncovered. Vulture, July 152013. Available at: http://www.vulture.com/2013/07/how-jk-rowlings-pseudonymwas-uncovered.html. Accessed in September 72014.

FUZER, Cristiane; CABRAL, Sara Regina Scotta. Introdução à gramática sistêmico-funcional em língua portuguesa. Campinas: Mercado das Letras, 2014

GALBRAITH, Robert. The Cuckoo's Calling. London: Mulholland Books, 2014.

GOOGLE Acadêmico. Available at: https://scholar.google.com.br/scholar?hl=pt-

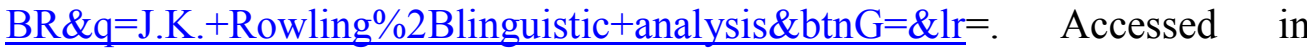
January 2016.

HALLIDAY, M.A.K; MATTHIESSEN, C. An Introduction to Functional Grammar. London: Arnould, 2004.

LINCOLN, Yvonna S.; GUBA, Egon G. Paradigmatic controversies, contradictions, and emerging confluences. In: GUBA, Egon G.; LINCOLN, Yvonna S. Handbook of qualitative research. $4^{\text {th }}$ ed. Thousand Oaks: Sage, 2011.

ROWLING, J. K. Harry Potter and the Philosopher's Stone. London: Bloomsburry, 1997.

SHAPIRO, Marc. J. K. Rowling: The Wizard Behind Harry Potter. New York: St. Martin's Press: 2007. 
VIAN JR., Orlando. Linguística sistêmico-funcional. IN: GONÇALVES, A. V.; GÓIS, M. L. S. (orgs.). Ciências da linguagem: o fazer científico, volume 2. Campinas: Mercado de Letras, 2014.

VINCENT, Alice. Rejection Letters: The Publishers Who Got It Embarrassingly Wrong... The Huffington Post UK, May 17 2012. Available at: http://www.huffingtonpost.co.uk /2012/05/16/publishers-who-got-it-wrong_n_1520190.html. Accessed on September 212014.

WATSON, Julie \& KELLNER, Tomas. J. K. Rowling and the Billion-Dollar Empire. Forbes .com, February 26 2004. Available at: http://www.forbes.com/maserati/ billionaires2004/cx jw 0226rowlingbill04.html. Accessed on September 7 2014.

ZAKS, David. How Did Computers Uncover J. K. Rowling's Pseudonym? Smithsonian Magazine March, 2014. Available at: http://www.smithsonianmag.com/science-nature/how-did-computers-uncoverjk-rowlings-pseudonym-180949824/?no-ist. Accessed on September 72014. 


\section{Appendix}

In this appendix, I list all excerpts I have chosen analyzed according to the markings presented on Table 5 (p. 19), according to processes, attributes and circumstances.

It is important to emphasize that I only analyzed the processes, circumstances and attributes related to the participant Harry Potter in Harry Potter and the Philosopher Stone and the participant Cormoran Stike in The Cuckoo's Calling in chapters 1 and 2 of both books.

\section{A.1 Harry Potter and the Philosopher Stone}

\section{A.1.1 Excerpts related to Harry Potter}

- HP-1

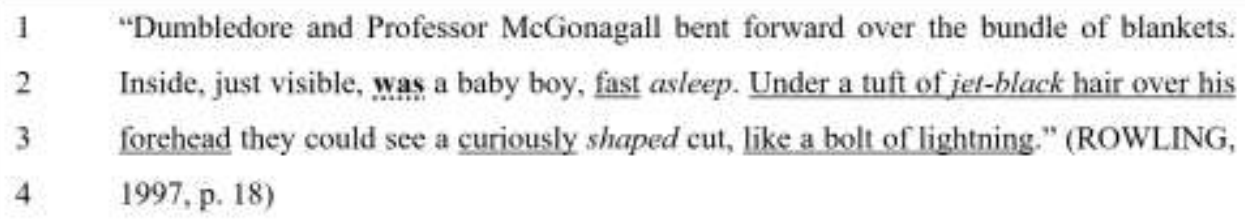

- HP-2

\footnotetext{
1 "Harry Potter rolled over inside his blankets without waking up. One small

2 hand closed on the letter beside him and he slept on, not knowing he was

3 special, not knowing he was famous, not knowing he would be woken in a

4 few hours' time by Mrs. Dursley's scream as she opened the front door to put

5 out the milk bottles, nor that he would spend the next few weeks being

6 prodded and pinched by his cousin Dudley..." (ROWLING, 1997, p. 18)
} 
- HP-3

1 "The room held no sign at all that another boy lived in the house, too.

2 Yet Harry Potter was still there, asleep at the moment, but not for long. His

3 Aunt Petunia was awake and it was her shrill voice which made the first noise

4 of the day.

5 'Up! Get up! Now!'

6 Harry woke with a start.

7 'Up,' she screeched. Harry heard her walking toward the kitchen and then

8 the sound of the frying pan being put on the stove. He rolled onto his back

9 and tried to remember the dream he had been having. It had been a good

10 one. There had been a flying motorcycle in it. He had a fumy feeling he'd

11 had the same dream before.

12 'Are you up yet?' she demanded.

13 'Nearly,' said Harry." (ROWLING, 1997, pp. 19, 20)

- HP-4

\begin{tabular}{|ll|}
\hline 1 & "Dudley's birthday - how could he have forgotten? Harry got slowly out \\
2 & of bed and started looking for socks. He found a pair under his bed and, after \\
3 & pulling a spider off one of them, put them on. Harry was used to spiders, \\
4 & because the cupboard under the stairs was full of them, and that was where \\
5 & he slept. \\
6 & When he was dressed he went down the hall into the kitchen." (ROWLING, \\
7 & 1997, p. 20)
\end{tabular}

\section{- HP-5}

1 "Dudley's favorite punching bag was Harry, but he couldn't often catch

2 him. Harry didn't look it, but he was very fast.

3 Perhaps it had something to do with living in a dark cupboard, but Harry

$4 \quad$ had always been small and skinny for his age. He looked even smaller and

5 skinnier than he really was because all he had to wear were old clothes of

6 Dudley's, and Dudley was about four times bigger than he was. Harry had a

7 thin face, knobbly knees, black hair, and bright green eyes. He wore round

8 glasses held together with a lot of Sellotape because of all the times Dudley

9 had punched him on the nose. The only thing Harry liked about his own

10 appearance was a very thin scar on his forehead that was shaped like a bolt

11 of lightning. He had had it as long as he could remember, and the first

12 question he could ever remember asking his Aunt Petunia was how

13 he had gotten it." (ROWLING, 1997, pp. 20) 
- HP-6

1 Uncle Vernon entered the kitchen as Harry was turning over the bacon.

2 'Comb your hair!' he barked, by way of a morning greeting.

3 About once a week, Uncle Vernon looked over the top of his newspaper and

4 shouted that Harry needed a haircut. Harry must have had more haircuts than

5 the rest of the boys in his class put together, but it made no difference, his hair

6 simply grew that way - all over the place.

7 Harry was frving eggs by the time Dudley arrived in the kitchen with his

8 mother. (ROWLING, 1997, pp. 20, 21)

- HP-7

1 "Harry often said that Dudley looked like a pig in a wig.

2 Harry put the plates of egg and bacon on the table, which was difficult as

3 there wasn't much room." (ROWLING, 1997, p. 21)

\section{- HP-8}

1 "Harry, who could see a huge Dudley tantrum coming on, began wolfing

2 down his bacon as fast as possible in case Dudley turned the table over."

3 (ROWLING, 1997, p. 21)

- HP-9

1 "Every year, Harry was left behind with Mrs. Figg, a mad old lady who

2 lived two streets away. Harry hated it there. The whole house smelled of

3 cabbage and Mrs. Figg made him look at photographs of all the cats she'd

4 ever owned.

5 'Now what?' said Aunt Petunia, looking furiously at Harry as though he'd

6 planned this." Harry knew he ought to feel sorry that Mrs. Figg had broken

7 her leg, but it wasn't easy when he reminded himself it would be a whole

8 year before he had to look at Tibbles, Snowy. Mr. Paws, and Tufty

9 again..." (ROWLING, 1997, p. 21) 
- HP-10

\begin{tabular}{|ll|}
\hline 1 & "The Dursleys often spoke about Harry like this, as though he wasn't there - \\
2 & or rather, as though he was something very nasty that couldn't understand \\
3 & them, like a slug. \\
4 & 'What about what's-her-name, your friend - Yvonne?' \\
5 & 'On vacation in Majorca,' snapped Aunt Petunia. \\
6 & 'You could just leave me here,' Harry put in hopefully (he'd be able to \\
7 & watch what he wanted on television for a change and maybe even have a go \\
8 & on Dudley's computer). \\
9 & Aunt Petunia looked as though she'd just swallowed a lemon. \\
10 & 'And come back and find the house in ruins?' she snarled. \\
11 & 'I won't blow up the house,' said Harry, but they weren't listening." \\
12 & (ROWLING, 1997, p. 22) \\
\hline
\end{tabular}

\section{- HP-11}

"Half an hour later, Harry, who couldn't believe his luck, was sitting in the back of the Dursleys' car with Piers and Dudley, on the way to the zoo for the first time in his life." (ROWLING, 1997, p. 23)

\section{- HP-12}

1 "I'm not going to do anything," said Harry, "honestly'."

2 But Uncle Vernon didn't believe him. No one ever did.

3 The problem was, strange things often happened around Harry and it was

4 just no good telling the Dursleys he didn't make them happen.

5 Once, Aunt Petunia, tired of Harry coming back from the barbers looking

6 as though he hadn't been at all, had taken a pair of kitchen scissors and cut

7 his hair so short he was almost bald except for his bangs, which she left "to

8 hide that horrible scar.' Dudley had laughed himself silly at Harry, who

9 spent a sleepless night imagining school the next day, where he was

10 already laughed at for his baggy clothes and taped glasses. Next morning,

11 however, he had gotten up to find his hair exactly as it had been before

12 Aunt Petunia had sheared it off. He had been given a week in his cupboard

13 for this, even though he had tried to explain that he couldn't explain how it

14 had grown back so quickly." (ROWLING, 1997, p. 23) 
- HP-13

1 "On the other hand, he'd gotten into terrible trouble for being found on the

2 roof of the school kitchens. Dudley's gang had been chasing him as usual

3 when, as much to Harry's surprise as anyone else's, there he was sitting on

4 the chimney. The Dursleys had received a very angry letter from Harry's

5 headmistress telling them Harry had been climbing school buildings. But

6 all he'd tried to do (as he shouted at Uncle Vernon through the locked door

7 of his cupboard) was jump behind the big trash cans outside the kitchen

8 doors. Harry supposed that the wind must have caught him in mid- jump."

9 (ROWLING, 1997, pp. 23, 24)

\section{- HP-14}

\begin{tabular}{|ll|}
\hline 1 & "'I had a dream about a motorcycle,' said Harry, remembering suddenly. \\
2 & 'It was flying." \\
3 & Uncle Vernon nearly crashed into the car in front. He turned right around in \\
4 & his seat and yelled at Harry, his face like a gigantic beet with a mustache: \\
5 & 'MOTORCYCLES DON'T FLY!' \\
6 & Dudley and Piers sniggered. \\
7 & 'I know they don't, said Harry. 'It was only a dream.' \\
8 & But he wished he hadn't said anything. If there was one thing the Dursleys \\
9 & hated even more than his asking questions, it was his talking about \\
10 & anything acting in a way it shouldn't, no matter if it was in a dream or even a \\
11 & cartoon -- they seemed to think he might get dangerous ideas." \\
12 & (ROWLING, 1997, p. 23)
\end{tabular}

\section{- HP-15}

1 "The Dursleys bought Dudley and Piers large chocolate ice creams at the

2 entrance and then, because the smiling lady in the van had asked Harry what

3 he wanted before they could hurry him away, they bought him a cheap

4 lemon ice pop. It wasn't bad, either, Harry thought, licking it as they

5 watched a gorilla scratching its head who looked remarkably like Dudley,

6 except that it wasn't blond.

7 Harry had the best morning he'd had in a long time. He was careful to

8 walk a little way apart from the Dursleys so that Dudley and Piers, who

9 were starting to get bored with the animals by lunchtime, wouldn't fall back

10 on their favorite hobby of hitting him. They ate in the zoo restaurant, and

11 when Dudley had a tantrum because his knickerbocker glory didn't have

12 enough ice cream on top, Uncle Vernon bought him another one and Harry

13 was allowed to finish the first.

14 Harry felt, afterward, that he should have known it was all too good to

15 last." (ROWLING, 1997, pp. 24, 25) 
- HP-16

1 "Harry moved in front of the tank and looked intently at the snake. He wouldn't have been surprised if it had died of boredom itself - no company except stupid people drumming their fingers on the glass trying to disturb it all day long. It was worse than having a cupboard as a bedroom, where the only visitor was Aunt Petunia hammering on the door to wake you up; at least he got to visit the rest of the house.

The snake suddenly opened its beady eyes. Slowly, very slowly, it raised its head until its eyes were on a level with Harry's.

It winked.

Harry stared. Then he looked quickly around to see if anyone was watching.

They weren't. He looked back at the snake and winked, too.

The snake jerked its head toward Uncle Vernon and Dudley, then raised its eyes to the ceiling. It gave Harry a look that said quite plainly: 'I get that all the time.'

'I know, 'Harry murmured through the glass, though he wasn't sure the snake could hear him. 'It must be really annoying.'

The snake nodded vigorously.

'Where do you come from, anyway?' Harry asked.

The snake jabbed its tail at a little sign next to the glass. Harry peered at it.

Boa Constrictor, Brazil.

'Was it nice there?'

The boa constrictor jabbed its tail at the sign again and Harry read on:

This specimen was bred in the zoo. 'Oh, I see - so you've never been to

Brazil?'

As the snake shook its head, a deafening shout behind Harry made both of them jump.

'DUDLEY! MR. DURSLEY! COME AND LOOK AT THIS SNAKE! YOU WON'T BELIEVE WHAT IT'S DOING!'

Dudley came waddling toward them as fast as he could.

'Out of the way, you,' he said, punching Harry in the ribs. Caught by surprise, Harry fell hard on the concrete floor. What came next happened so fast no one saw how it happened - one second, Piers and Dudley were leaning right up close to the glass, the next, they had leapt back with howls of horror.

Harry sat up and gasped; the glass front of the boa constrictor's tank had vanished. The great snake was uncoiling itself rapidly, slithering out onto the floor. People throughout the reptile house screamed and started running for the exits.

As the snake slid swiftly past him, Harry could have sworn a low, hissing voice said, 'Brazil, here I come.... Thanksss, amigo.' (ROWLING, 1997, pp. 25,26$)$ 
- HP-17

\begin{tabular}{|c|c|}
\hline 1 & 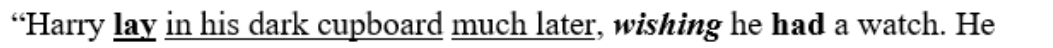 \\
\hline 2 & didn't know what time it was and he couldn't be sure the Dursleys were \\
\hline 3 & asleep yet. Until they were, he couldn't risk sneaking to the kitchen for \\
\hline 4 & some food. \\
\hline 5 & He'd lived with the Dursleys almost ten years, ten miserable years, as long \\
\hline 6 & as he could remember, ever since he'd been a baby and his parents had died \\
\hline 7 & in that car crash. He couldn't remember being in the car when his parents \\
\hline 8 & had died. Sometimes, when he strained his memory during long hours in his \\
\hline 9 & cupboard, he came up with a strange vision: a blinding flash of green light \\
\hline 10 & and a burning pain on his forehead. This, he supposed, was the crash, \\
\hline 11 & though he couldn't imagine where all the green light came from. He \\
\hline 12 & couldn't remember his parents at all. His aunt and uncle never spoke about \\
\hline 13 & them, and of course he was forbidden to ask questions. There were no \\
\hline 14 & photographs of them in the house. \\
\hline 15 & When he had been younger, Harry had dreamed and dreamed of some \\
\hline 16 & unknown relation coming to take him away, but it had never happened; \\
\hline 17 & the Dursleys were his only family. Yet sometimes he thought (or maybe \\
\hline 18 & hoped) that strangers in the street seemed to know him. Very strange \\
\hline 19 & strangers they were, too. A tiny man in a violet top hat had bowed to him \\
\hline 20 & once while out shopping with Aunt Petunia and Dudley. After asking Harry \\
\hline 21 & furiously if he knew the man, Aunt Petunia had rushed them out of the shop \\
\hline 22 & without buying anything. A wild-looking old woman dressed all in green \\
\hline 23 & had waved merrily at him once on a bus. A bald man in a very long purple \\
\hline 24 & coat had actually shaken his hand in the street the other day and then walked \\
\hline 25 & away without a word. The weirdest thing about all these people was the way \\
\hline 26 & they seemed to vanish the second Harry tried to get a closer look. \\
\hline 27 & At school, Harry had no one. Everybody knew that Dudley's gang hated that \\
\hline 28 & odd Harry Potter in his baggy old clothes and broken glasses, and nobody \\
\hline 29 & liked to disagree with Dudley's gang." (ROWLING, 1997, p. 27) \\
\hline
\end{tabular}

\section{A.2 The Cuckoo's Calling}

\section{A.2.1 Excerpts related to Cormoran Strike}

\section{- CS-1}

1 The name on the paper beside the outside buzzer was engraved on the glass

2 panel: C. B. Strike, and, underneath it, the words Private Detective."

3 (GALBRAITH, 2013, p. 17) 
- CS-2

1 Strike absorhed the impact, heard the high-pitched scream and reacted

2 instinctively: throwing out a long arm, he seized a fistful of cloth and flesh;

3 a second shriek of pain echoed around the stone walls and then, with a

4 wrench and a tussle, he had succeeded in dragging the girl back on to firm

5 ground. Her shrieks were still echoing off the walls, and he realized that he

6 himself had bellowed, 'Jesus Christ!'” (GALBRAITH, 2013, p. 18)

\section{- CS-3}

1 Judging by the lopsided way she was hunched, with one hand buried deep

2 under the lapel of her coat, Strike deduced that he had saved her by

3 grabbing a substantial part of her left breast. A thick, wavy curtain of bright

4 blonde hair hid most of the girl's blushing face, but Strike could see tears of

5 pain leaking out of one uncovered eye.

6 'Fuck - sorry!' His loud voice reverberated around the stairwell. "I didn't

7 see you-didn't expect anyone to be there..." (GALBRAITH, 2013, p. 18)

\section{- CS-4}

$1 \quad$ "'Come in here..."

2 Strike pushed open the door with his fingertips, so as to have no accidental

3 contact with her while she stood huddled against it, and ushered her into the office.

4 "Is everything all right?" called the graphic designer querulously.

5 Strike slammed the office door behind him." (GALBRAITH, 2013, p. 19)

\section{- CS-5}

\begin{tabular}{|ll|}
\hline 1 & Her accidental assailant was massive, his height, his general hairiness, \\
2 & coupled with a gently expanding belly, suggested a grizzly bear. One of his \\
3 & eyes was puffy and bruised, the skin just below the eyebrow cut. Congealing \\
4 & blood sat in raised white-edged nail tracks on his left cheek and the right \\
5 & side of his thick neck, revealed by the crumpled open collar of his shirt. \\
6 & (GALBRAITH, 2013, p. 19)
\end{tabular}

\section{- CS-6}

\begin{tabular}{|ll|}
\hline 1 & "The name of the agency did not wipe the incredulous look from his \\
2 & battered face. They stared at each other, unnerved and antagonistic. \\
3 & Just like Robin, Cormoran Strike knew that he would forever remember the \\
4 & last twelve hours as an epoch-changing night in his life. Now, it seemed, the \\
5 & Fates had sent an emissary in a neat beige trench coat, to taunt him with the \\
6 & fact that his life was bubbling towards catastrophe. There was not supposed \\
7 & to be a temp. He had intended his dismissal of Robin's predecessor to end \\
8 & his contract." (GALBRAITH, 2013, p. 20)
\end{tabular}


- $\mathrm{CS}-7$

1 "Strike made a rapid mental calculation. A week at the agency's exorbitant

2 rate would drive his overdraft yet further into the region of irreparable; it

3 might even be the final straw his main creditor kept implying he was

4 waiting for.

$5 \quad$ "Scuse a moment',

6 He left the room via the glass door, and turned immediately right, into a

7 tiny dank toilet. Here he bolted the door, and stared into the cracked, spotted

8 mirror over the sink.

9 The reflection staring back at him was not handsome. Strike had the high,

10 bulging forehead, broad nose and thick brows of a young Beethoven who

11 had taken to boxing, an impression only heightened by the swelling and

12 blackening eye. His thick curly hair, springy as carpet, had ensured that his

13 many youthful nicknames had included "Pubehead." He looked older than

14 his thirty-five years." (GALBRAITH, 2013, p. 20)

\section{- CS-8}

\begin{tabular}{|ll|}
\hline 1 & "Ramming the plug into the hole, he filled the cracked and grubby sink \\
2 & with cold water, took a deep breath and completely submerged his \\
3 & throbbing head. Displaced water slopped over his shoes, but he ignored it \\
4 & for the relief of ten seconds of icy, blind stillness. \\
5 & Disparate images of the previous night flickered through his mind: \\
6 & emptving three drawers of possessions into a kitbag while Charlotte \\
7 & screamed at him; the ashtray catching him on the brow-bone as he looked \\
8 & back at her from the door; the journey on foot across the dark city to his \\
9 & office, where he had slept for an hour or two in his desk chair. Then the \\
10 & final, filthy scene, after Charlotte had tracked him down in the early \\
11 & hours, to plunge in those last few banderillas she had failed to implant \\
12 & before he had left her flat; his resolution to let her go when, after \\
13 & clawing his face, she had run out of the door; and then that moment of \\
14 & madness when he had plunged after her - a pursuit ended as quickly as \\
15 & it had begun, with the unwitting intervention of this heedless, \\
16 & superfluous girl, whom he had been forced to save, and then placate. \\
17 & He emerged from the cold water with a gasp and a grunt, his face and \\
18 & head pleasantly mumb and tingling. With the cardboard-textured towel \\
19 & hat hung on the back of the door, he rubbed himself dry and stared \\
20 & again at his grim reflection," (GALBRAITH, 2013 , pp. 20, 21)
\end{tabular}


- CS-9

\begin{tabular}{|c|c|}
\hline 1 & "Perhaps he ought to be glad that the Temporary Solution had forced him \\
\hline 2 & to abandon the chase. There could be no going back from the scene in the \\
\hline 3 & early hours of this morning. This time, it had to be over. \\
\hline 4 & Tugging his sodden collar away from his neck, Strike pulled back the rusty \\
\hline 5 & bolt and headed out of the toilet and back through the glass door. \\
\hline 6 & A pneumatic drill had started up in the street outside. Robin was standing in \\
\hline 7 & front of the desk with her back to the door; she whipped her hand back out of \\
\hline 8 & the front of her coat as he re-entered the room, and he knew that she had \\
\hline 9 & been massaging her breast again. \\
\hline 10 & 'Is - are you all right?' Strike asked, carefully not looking at the site of the \\
\hline 11 & injury. \\
\hline 12 & 'I'm fine. Listen, if you don't need me, I'll go,' said Robin with dignity. \\
\hline 13 & 'No-no, not at all,' said a voice issuing from Strike's mouth, though he \\
\hline 14 & listened to it with disgust. "A week - yeah, that'll be fine. Er - the post's \\
\hline 15 & here..." He scooped it from the doormat as he spoke and scattered it on the \\
\hline 16 & bare desk in front of her, a propitiatory offering. 'Yeah, if you could open \\
\hline 17 & that, answer the phone, generally sort of tidy up-computer password's \\
\hline 18 & Hatherill23, I'll write it down...' This he did, under her wary, doubtful \\
\hline 19 & gaze. "There you go-I'll be in here." (GALBRAITH, 2013, pp. 21, 22) \\
\hline
\end{tabular}

\section{- CS-10}

\begin{tabular}{|ll|}
\hline 1 & He strode into the inner office, closed the door carefully behind him and \\
2 & then stood quite still, gazing at the kitbag under the bare desk. It contained \\
3 & everything he owned, for he doubted that he would ever see again the nine \\
4 & tenths of his possessions he had left at Charlotte's. They would probably be \\
5 & gone by lunchtime; set on fire, dumped in the street, slashed and crushed, \\
6 & doused in bleach. The drill hammered relentlessly in the street below. \\
7 & And now the impossibility of paving off his mountainous debts, the \\
8 & appalling consequences that would attend the imminent failure of this \\
9 & business, the looming, unknown but inevitably horrible sequel to his leaving \\
10 & Charlotte; in Strike's exhaustion, the misery of it all seemed to rear up in \\
11 & front of him in a kind of kaleidoscope of horror. \\
12 & Hardly aware that he had moved, he found himself back in the chair in \\
13 & which he had spent the latter part of the night. From the other side of the \\
14 & insubstantial partition wall came muffled sounds of movement. The \\
15 & Temporary Solution was no doubt starting up the computer, and would \\
16 & shortly discover that he had not received a single work-related email in \\
17 & three weeks. Then, at his own request, she would start opening all his final \\
18 & demands. Exhansted, sore and hungry, Strike slid face down on to the desk \\
19 & again, muffling his eyes and ears in his encircling arms, so that he did not \\
20 & have to listen while his humiliation was laid bare next door by a stranger." \\
21 & (GALBRAITH, 2013, pp. 22, 23) \\
\hline
\end{tabular}

